\title{
Depression and Cardiovascular Disease: The Viewpoint of Platelets
}

\author{
Patrizia Amadio $1, * \mathbb{(})$, Marta Zarà ${ }^{1}\left(\mathbb{D}\right.$, Leonardo Sandrini ${ }^{1}\left(\mathbb{D}\right.$, Alessandro Ieraci ${ }^{2}(\mathbb{D}$ and \\ Silvia Stella Barbieri 1,*(D) \\ 1 Unit of Brain-Heart Axis: Cellular and Molecular Mechanism, Centro Cardiologico Monzino IRCCS, \\ 20138 Milan, Italy; marta.zara@ccfm.it (M.Z.); leonardo.sandrini@ccfm.it (L.S.) \\ 2 Laboratory of Neuropsychopharmacology and Functional Neurogenomics, Department of Pharmaceutical \\ Sciences, University of Milan, 20133 Milan, Italy; alessandro.ieraci@unimi.it \\ * Correspondence: patrizia.amadio@ccfm.it (P.A.); silvia.barbieri@ccfm.it (S.S.B.); Tel.: +39-02-58002 (P.A.); \\ +39-02-58002021 (S.S.B.)
}

Received: 18 September 2020; Accepted: 9 October 2020; Published: 13 October 2020

check for updates

\begin{abstract}
Depression is a major cause of morbidity and low quality of life among patients with cardiovascular disease (CVD), and it is now considered as an independent risk factor for major adverse cardiovascular events. Increasing evidence indicates not only that depression worsens the prognosis of cardiac events, but also that a cross-vulnerability between the two conditions occurs. Among the several mechanisms proposed to explain this interplay, platelet activation is the more attractive, seeing platelets as potential mirror of the brain function. In this review, we dissected the mechanisms linking depression and CVD highlighting the critical role of platelet behavior during depression as trigger of cardiovascular complication. In particular, we will discuss the relationship between depression and molecules involved in the CVD (e.g., catecholamines, adipokines, lipids, reactive oxygen species, and chemokines), emphasizing their impact on platelet activation and related mechanisms.
\end{abstract}

Keywords: platelets; depression; catecholamines; adipokines; low density lipoproteins; reactive oxygen species; chemokines

\section{Introduction}

Cardiovascular disease (CVD), still the most common cause of death worldwide [WHO, The Top 10 Causes of Death, https://www.who.int/news-room/fact-sheets/detail/the-top-10-causes-of-death, Accessed date: 20 June 2019], remains the major target for public health efforts. The association between psychosocial factors and CVDs has long been recognized, and a recent meta-analysis of prospective epidemiological studies found that psychological factors predict cardiovascular morbidity and mortality [1,2]. Specifically, depression has been associated with coronary heart disease (CHD) $[3,4]$, and with atrial fibrillation [5,6]. After acute coronary syndrome (ACS), depression is a risk factor for all cause and cardiac mortality, as well as for composite outcomes including mortality or non-fatal cardiac events [7]. However, the relationship between depression and CVD is multifaceted and bidirectional: not only depression may increase the risk of CVD, but also cardiovascular events may increase the risk of depression [8]. The vast majority of studies are not able to determine whether this association is causative or temporally related, raising the eternal chicken-and-egg dilemma.

Behavioral factors, autonomic dysregulation, activation of the hypothalamic-pituitary-adrenal (HPA)-axis, inflammatory response [3], oxidative stress [9], serotoninergic and neurotrophins pathway dysregulation [10-12], endothelial dysfunction and platelet activation [3] are the proposed mechanisms underlying this relationship. 
Among these mechanisms, the platelet activation is one of the most attractive, seeing platelets as a potential mirror of the brain (dys)-function [13]. Indeed, even though platelet and neurons are basically different cells, they share common characteristics in subcellular organization [14] and in protein composition [15-21], representing as consequence an alternative tool to investigate neuronal dysfunction as well as a peripheral tracer of the onset and progression of brain-related pathologies.

Moreover, the platelet hyper-reactivity could at least partially explain the increased vulnerability of depressed patients to acute thrombotic event and ischemic heart disease [22], as well as their increased mortality post-myocardial infarction [23].

Of note, platelets of depressed patients display a greater exposure of anionic phosphatidylserine determinants, an increased activation of glycoprotein (GP) IIb/IIIa [22], a greater granules secretion [24], a higher expression of P-selectin and GPIb [25,26], and an enhanced aggregation in response to collagen and thrombin compared to control subjects [22,27], whereas platelet aggregation is unchanged when Adenosine Diphosphate (ADP) and TRAP1-6 were used [22,26,27] (Figure 1). An extensively investigated molecule in the relation between depression and platelets activation is the serotonin (5-HT) $[28,29]$. Platelets share with serotoninergic neurons several similarities in 5-HT uptake, storage, metabolism and release mechanisms, representing a good surrogate to study neuropsychiatric research [30]. Of note, platelets from depressed patients show a greater aggregation in response to 5-HT [31-33], display enhanced platelet serotonin uptake [30], that favors platelet response to ADP [34], and an increased platelet 5- $\mathrm{HT}_{2}$ receptor binding and density $[35,36]$ (Figure 1). Despite the already proved importance of 5-HT in this contest also other circulating molecules may be involved.

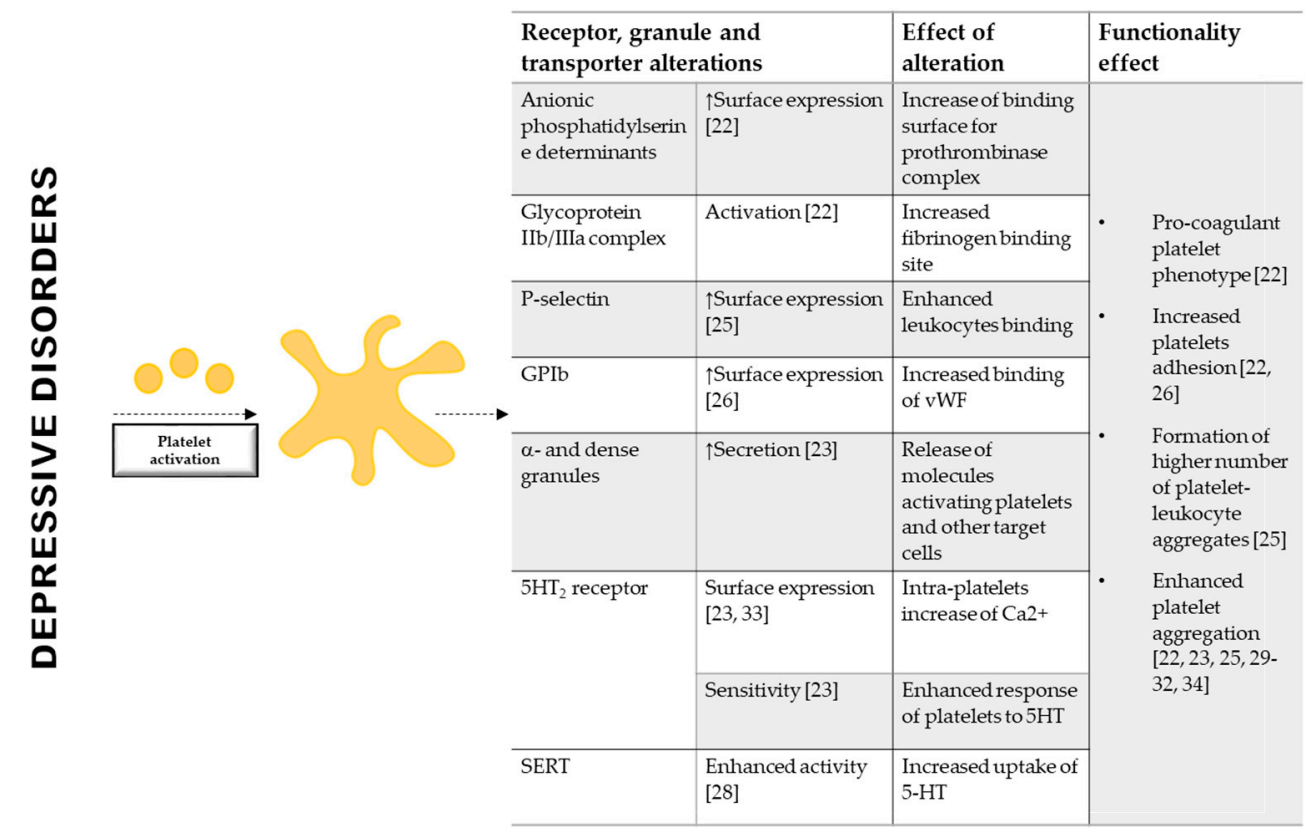

Figure 1. Platelets of depressed patients show hyper-reactivity. Patients with depression, show hyper-reactive platelets. Indeed, platelets of depressed patients display a greater exposure of anionic phosphatidylserine determinants, an increased activation of Glycoprotein $\mathrm{Ilb} / \mathrm{III}$, a higher expression of P-selectin and Glycoprotein $\mathrm{Ib}$, an increased expression and sensitivity of $5 \mathrm{HT}_{2}$ receptor, an enhanced activity of SERT and an enhanced aggregation and sensitivity in response to collagen thrombin, and serotonin. Platelet hyper-reactivity is also confirmed by a greater platelet granules secretion. GP: Glycoprotein; vWF: von Willebrand Factor; 5-HT: 5-Hydroxytriptamine; 5-HT 2 : 5-HT receptor; SERT: plasma membrane serotonin transporter. $\uparrow$ : increased compared to control.

This review will be focused on the prothrombotic state of patients affected by depressive disorders. In particular, it will analyze the impact of catecholamines, adipokines, lipids, reactive oxygen species 
and chemokines, in the pathophysiological link between depression and CVD, emphasizing the critical role of platelet activation and the related molecular mechanisms.

\section{Catecholamines}

The catecholamines are adaptive and maladaptive stress hormones; they activate behavioral and physiological processes facilitating the overcoming of stress [37]. Endogenous catecholamines include dopamine (DA), noradrenaline (norepinephrine/NE), and adrenaline (epinephrine/EPI) [37]. Catecholamines, produced and released by the sympathetic system, brain and adrenal medulla [37], exert their effects on multiple organs/compartments [38]. Although catecholamines are essential constituents of physiologic cardiovascular regulation, their effects are greatly emphasized by abnormal conditions [39].

The response to EPI and NE is mediated by a set of G protein-coupled adrenergic receptors (ARs), $\alpha$ and/or $\beta$-adrenergic receptors, that are targets for several cardiovascular drugs [37,40]. DA receptors are all members of the $G$ protein-coupled receptor family and they are divided into two subtypes: D1-like receptors coupled with Gs alpha subunit (Gs) (D1 and D5) and D2-like receptors coupled with Gi alpha subunit (Gi) (D2, D3, D4). NE, EPI and DA have a prominent position in the pathogenic mechanisms of several cardiovascular disorders, such as angina pectoris, heart failure, arterial hypertension, atherosclerosis and thrombosis [39,41].

\subsection{Catecholamines in Depression}

The discovery, in the 1960s, that the inhibition of neuronal uptake of NE, the primary target for tricyclic antidepressants, reduced depressive symptoms, led to hypothesize and then to show that a deficit in catecholamine transmission could account for the depression [42]. On the other hand, the contribution of DA was largely neglected until few years ago.

Beyond alterations in adrenergic and dopaminergic receptors availability, and the consequent modification in the downstream pathways in the brain [43-46], depressive disorders have been also associated with changing in peripheral levels of catecholamines.

In spite of the scarce and outdated studies, plasma levels of EPI and NE result increased in depressed patients and their levels correlate with the severity of the pathology [47,48]. In agreement with previous data, more recent studies showed that patients suffering from depression and other major affective disorders have increased urinary levels of EPI, NE and DA [49], and the existence of a positive association between urinary EPI or NE and depressive symptoms [50] (Table 1).

All these findings provide the evidence that alterations in peripheral catecholamines levels may be relevant also in depression and not only in stress response, and pave the way to the potential link among catecholamines, depression and CVDs.

\subsection{Catecholamines and Platelet Function}

Since human platelets express both adrenergic and dopaminergic receptors [51-53], the high catecholamine levels may easier explain the association between depression and CVD. Basically, through platelet $\alpha 2$-adrenergic or dopaminergic receptors, they modulate thrombopoiesis [54,55], and platelet function [56-58]. Low concentrations of catecholamines and dopamine potentiate the effects of other agonists (e.g., ADP, collagen, and thrombin) enhancing platelet aggregation, whereas at high concentrations are sufficient alone to induce human platelet aggregation, granule secretion, and release of platelet markers (e.g., Platelet Factor 4 (PF4) and $\beta$-thromboglobulin (BTG) [59-61] (Table 1).

Specifically, the effects of EPI on human platelet activation has been extensively investigated in vitro providing the evidence that in platelet $\alpha 2$-adrenergic receptors are selectively coupled to $\mathrm{Gz}$ family members but not to Gq or G12 family members [62]. The activation of Gz mediated by EPI, inhibits cyclic Adenosine Monophosphate (cAMP) formation and promotes the activation of Rap1B and PI 3-kinase [63], enhancing the effects of other agonists. Interestingly, EPI, not affecting Phospholipase $\mathrm{C}$ (PLC), is unable to cause platelet shape change [64]. 
Remarkable, EPI infusion induces a threefold increase of platelet thromboxane (TX) production [65], and enhances platelet fibrinogen binding and platelet aggregation induced by thrombin [66].

In vivo infusion or in vitro exposure to EPI, enhances ADP-induced platelet aggregation and clot formation both in healthy subjects treated with ticagrelor and in ACS patients under acetylsalicylic acid and ticagrelor therapy $[67,68]$ (Table 1 ).

Table 1. Catecholamines levels in MDD and effect on megakaryocytes and platelets.

\begin{tabular}{|c|c|c|c|c|}
\hline \multicolumn{5}{|c|}{ Catecholamines in Depression and Platelets } \\
\hline \multicolumn{2}{|r|}{ DEPRESSION } & \multicolumn{3}{|c|}{ EFFECT ON MEGAKARYOCYTES } \\
\hline Stimulus & Levels & Stimulus & Receptor & Effect \\
\hline $\begin{array}{l}\text { EPI } \\
\text { NE }\end{array}$ & $\begin{array}{l}\text { Increased circulating and } \\
\text { urinary levels [47-49] }\end{array}$ & $\begin{array}{l}\text { EPI } \\
\text { NE }\end{array}$ & $\begin{array}{c}\alpha-2- \\
\text { adrenoceptor }\end{array}$ & $\begin{array}{l}\text { Megakaryocyte adhesion and } \\
\text { migration [55] } \\
\text { Pro-platelets formation [55] }\end{array}$ \\
\hline \multirow[t]{2}{*}{ DA } & $\begin{array}{l}\text { Increased urinary levels } \\
{[49]}\end{array}$ & DA & D1/D2 & Megakaryocytes differentiation [54] \\
\hline & & \multicolumn{3}{|c|}{ EFFECT ON PLATELETS } \\
\hline Stimulus & Levels & Stimulus & Receptor & Effect \\
\hline \multirow{2}{*}{$\begin{array}{l}\text { EPI } \\
\text { NE }\end{array}$} & \multirow{2}{*}{$\begin{array}{l}\text { Increased circulating and } \\
\text { urinary levels [47-49] }\end{array}$} & $\begin{array}{l}\text { EPI } \\
\text { NE }\end{array}$ & $\begin{array}{c}\alpha-2- \\
\text { adrenoceptor }\end{array}$ & $\begin{array}{c}\text { Low concentrations: } \\
\text { Increase the sensitivity to collagen, } \\
\text { thrombin and ADP }[52,56,57,60]\end{array}$ \\
\hline & & EPI & $\begin{array}{l}\alpha-2- \\
\text { adrenoceptor }\end{array}$ & $\begin{array}{c}\text { High concentrations: } \\
\text { Induce aggregation alone }[57,66] \\
\text { Increase TX production [65] } \\
\text { Enhance fibrinogen binding [66] } \\
\text { Induce clot formation [65-67] }\end{array}$ \\
\hline \multirow{3}{*}{ DA } & \multirow{3}{*}{$\begin{array}{l}\text { Increased urinary levels } \\
{[49]}\end{array}$} & \multirow{2}{*}{ DA } & D2 (?) & $\begin{array}{l}\text { Low concentrations: } \\
\text { Increase sensitivity to ADP [61] }\end{array}$ \\
\hline & & & $\begin{array}{l}\text { D2-like } \\
\text { receptor }\end{array}$ & $\begin{array}{c}\text { Induce platelet microaggregation } \\
\text { [58] } \\
\text { Induce platelet adhesion [58] }\end{array}$ \\
\hline & & & D2 (?) & $\begin{array}{l}\text { High concentrations: } \\
\text { Induce the release of a-granules [61] }\end{array}$ \\
\hline
\end{tabular}

EPI: Epinephrine; NE: Norepinephrine; DA: Dopamine; D1/D2: Dopamine Receptors; ADP: Adenosine diphosphate; PF: Platelet Factor 4. ?: still under debate.

Despite NE induces platelet activation by binding, like EPI, $\alpha 2$-adrenergic receptors, its action is two or three times less effective than EPI [52,60] (Table 1).

Finally, dopamine potentiates platelet microaggregate formation and adhesion to collagen under low shear flow induced by ADP via D2-like receptor [58] (Table 1), however dopamine infusion in hypertensive and normotensive men do not influence platelet count, platelet size and plasma concentration of $\beta$-thromboglobulin [69].

Overall these data suggest that the inappropriate activation of the sympathoadrenal axis occurring under depression may increase the sensitivity of circulating platelets to agonists with severe consequences on CVD outcome.

\section{Adipokines}

Neuroendocrine regulators of energy metabolism are crucial in determining cardiovascular risk [70], and are associated with depression disorders [71]. In this contest, adipose tissue plays an endocrine role by synthesizing and secreting bioactive compounds named adipokines, whose secretion is essential to energy and metabolic homeostasis [72]. The most studied adipokines are leptin and adiponectin, whose alteration is reflected on both neuronal [73] and cardiovascular alterations [74,75]. 
Of note, among classical adipokines, also non-conventional metabolic regulators, like neurotrophins, could play a pivotal role in influencing both these pathology [76].

\subsection{Leptin}

Leptin is a hormone mainly secreted by adipocytes, it is involved in the control of food intake [77] and its increased levels are associated to obesity [78]. The peripheral actions of leptin include stimulation of inflammatory reaction, oxidative stress, atherosclerosis and thrombosis, thus promoting endothelial dysfunction, arterial stiffness, development and vulnerability of atherosclerotic plaques [79]. Moreover, it has been reported that $\mathrm{CHD}$ patients have higher leptin levels compared to controls [80,81]. Its serum concentrations are increased after myocardial infarction (MI) [82], and its high levels are associated with an increased risk of cardiac death, ACS, non-fatal MI, stroke and hospitalization for congestive heart failure $[83,84]$.

\subsubsection{Leptin in Depression}

Modifications of leptin metabolism and its gene expression, as well as its receptor, have been reported among patients with mental health disorders, including depression [85], independently of drug treatment [86]. However, the relationship between circulating leptin levels and depression is under debate. Some authors stated that depression is associated with low circulating and brain leptin levels [87-90], suggesting a correlation between leptin levels and the depressive mood. This data are supported by the observation that administration of leptin exerts an antidepressant-like effect [91], through dopaminergic neurotransmission regulation in mesolimbic areas [92]. In particular, leptin reduces symptoms of depression and has an anxiolytic effect affecting the HPA [93,94], and stimulating brain-derived neurotrophic factor (BDNF) production and function [95-97]. In addition, the deletion of leptin receptor (LepRb) and its downregulation are associated with depression-like behavioral impairments, indicating that leptin-lepRb signaling is involved in the molecular mechanism of leptin antidepressant action [98,99].

On the other hand, some studies did not find any difference in the leptin levels between depressed patients and control group [100-103], or measured higher levels of leptin in depressed patients [104-109]. In addition, a positive association between circulating leptin levels and depressive symptoms [110], mild/moderate but not severe depression [104,111], and with self-reported depressive symptoms, especially in women [109], was recently identified. A marked sexual difference in leptin levels has been consistently reported, usually both healthy and depressed women have higher leptin levels than men $[88,104,112]$. Several reasons of these sex-discrepancies have been hypothesized, including: (a) the greater amount of subcutaneous and intra-abdominal adipose tissue in women (b) the difference in male and female eating behavior or upregulated leptin mRNA in proportionally larger adipocytes of females and (c) the testosterone levels, that inversely correlates with leptin levels [113].

In general, confounders such as time of blood sampling, age, Body Mass Index (BMI), gender-associated metabolic disturbances, medication history and clinical type and features of depressive disorders, might impact peripheral leptin levels, and thereby justify inconsistent results obtained [101,104,107,114,115].

The presence of atypical major depressive disorders (MDD) may be an additional explanation of this contradictory results. High concentrations of leptin are specifically associated with atypical MDD and with symptoms that represent the core features of the atypical subtype, whereas no association was found for the typical subtype or when considering the general diagnosis of MDD [106]. This finding is consistent with the hypothesis of a leptin resistance process which blunts leptin central action, despite increasing peripheral concentrations, and leads to hyper-leptinemia in obese subjects [106]. Data from a large international consortium identified that $15 \%$ of patients with atypical depression carried a higher number of genetic risk variants for increased BMI, leptin and C-reactive protein $(\mathrm{CRP})$, meaning that atypical depression and obesity-related traits may be the two faces of the same syndrome [108]. 
Taken together, all these data indicate the necessity of further investigation about circulating leptin levels in depressive disorders to understand its real impact on cardiovascular risk and thrombosis.

\subsubsection{Leptin and Platelet Function}

Among other receptors, platelets express on their surface also receptors for peptide hormones, including the long form of leptin receptor (LEPRL) [116], suggesting that alteration of leptin levels occurring in depressive disorders may alter platelet response contributing to cardiovascular complications. Indeed, leptin promotes arterial thrombosis, potentiates platelet aggregation in mouse $[117,118]$, increases platelets adhesion and potentiates ADP- and thrombin-induced aggregation in human [119,120], even if such effect was not observed in all subjects [116-118,121-123].

Furtherly, it has been shown that leptin induces platelet activation through almost two different signaling cascade mechanisms. The first includes the activation of Janus kinase 2 (JAK2), phosphatidylinositol 3-kinase (PI3K), protein kinase B (PKB), insulin receptor substrate-1 (IRS-1), and phosphodiesterase 3A (PDE3A), with a consequent increase of PDE3A and a decrease of cAMP $[119,120]$. The second one leads to GPIIb/IIIa activation, increase of $\mathrm{Ca}^{2+}$ and TX production through the activation of phospholipase $\mathrm{C} \gamma 2$ (PLC $\gamma 2$ ), protein kinase $C$ (PKC), and phospholipase $\mathrm{A}_{2}\left(\mathrm{PLA}_{2}\right)$ pathway [124].

\subsection{Adiponectin}

Adiponectin is an anti-inflammatory adipokine and contributes to increase insulin sensitivity protecting, therefore, against diabetes, atherosclerosis and thrombosis. Accordingly, high concentrations of adiponectin have been associated with a reduction in the risk of CVD [125-127] and an increase in endothelial nitric oxide production [128]. Conversely, patients with CVD, with increased carotid intima-media thickness and with obesity, exhibit low plasma adiponectin levels [129].

\subsubsection{Adiponectin in Depression}

The relationship and the modulation of adiponectin in depressive disorders have been extensively studied. Specifically, several studies and a recent meta-analysis showed that MDD patients have low adiponectin levels $[105,130-134]$, and that successfully antidepressant treatment increases its levels [135]. Interestingly, an inverse correlation between adiponectin levels and Hamilton Depression Rating Scale (HAM-D), indicating the depression symptoms severity at admission $[130,132,136]$, or cumulative duration of depression [137] was identified. However, other studies were unable to confirm this observation [103,138-140]. Again, several confounding factors have to be taken into consideration. It is well known that (a) ethnic difference $[140,141]$ between Asians and Europeans due to different body composition and metabolic profile [142], (b) matrix in which adiponectin is measured (plasma or serum) [134], (c) sex-dependent adiponectin levels [132,143], (d) body weight [137], (e) presence of metabolic syndrome [144], (f) onset of depressive event [107], and (g) the subtypes of depressive disorders [133,145-147] influence adiponectin levels.

However, when the modification of adiponectin levels are presents, they may contribute to platelet activation and then to thrombosis.

\subsubsection{Adiponectin and Platelet Function}

Concerning the impact of adiponectin on platelet function, both mice and human platelets express adiponectin receptors AdipoR1 and AdipoR2 [124]. Adiponectin alone does not affect platelet adhesion/aggregation in human [120], nevertheless its deletion in a mouse model increases agonist-induced platelet aggregation and enhances thrombus formation after photochemically-induced arterial injury [148]. The antithrombotic effect of adiponectin may be related to its ability to influence leukocytes behavior, to reduce polymorphonuclear (PMN) leukocyte- and monocyte-platelet aggregates [149], and to inhibit macrophage-related Tissue Factor (TF) expression and activity with the consequent impairment in the coagulation cascade [150]. 


\subsection{Neurothrophins}

The neurotrophin (NT) family consists of Nerve Growth Factor (NGF), BDNF, NT-3 and NT-4 (also named NT-4/5). NTs not only are stimulators of nerve growth, survival and differentiation [151] but they also exert effects on immune cells [152-154], blood vessels/angiogenesis [155,156], wound healing and tissue repair [156,157], and most importantly on glucose, lipid and energy dynamics [158-161]. They are considered key regulators of metabolism [162], and for their pleiotropic functions, NTs have, as consequence, a huge importance in both depression [76], and CVD [76].

BDNF influences endothelial function [163], monocyte activation [154], and thrombus dimension and stability [164]. It takes part to cardiovascular development [165] but also to the onset of cardiovascular alterations and disease [166], including hypertension [167,168], atherosclerosis [169,170] and thrombosis. Reduced BDNF plasma levels has been found in metabolic syndrome [170], ACS [171, 172], and type 2 diabetes [173], suggesting that alterations in its circulating levels may be associated to pathological conditions.

NGF and NT-3, similarly to BDNF, are involved in the cardiac development [174] and regeneration [175], angiogenetic process [165,176], hypertension onset $[76,177]$, and atherosclerotic lesions formation [170,172,178].

The role of NT-4 and related pathways in CVD are not well characterized; however, binding the same receptor of BDNF (Tropomyosin receptor kinase B-TrkB), it might have similar functions of BDNF in controlling blood pressure [168].

Interestingly, several NT polymorphisms, including BDNF rs6265 (Val66Met) [179-183], NGF rs11102930 [184] and rs78701042 [185], have been associated to increased risk of ACS and adverse outcome.

\subsubsection{Neurotrophins in Depression}

By their nature NTs play a key role in preventing depressive disorders [186], and data obtained in rodent models of depression indicate that administration of BDNF and NGF have significant antidepressant effects $[187,188]$. NTs do not control directly mood but, they are fundamental in the activity-dependent modulation of networks and changes in plasticity [11]. Low NT levels have been associated with several affective disorders including bipolar depression (BD) $[189,190]$, depression [12,191], mania [192], and obsessive compulsive disorders [193]. In particular, reductions in serum and plasma BDNF have been found in patients affected by depression [194-196], and in those who committed suicide [197,198]. Despite a large cohort study [199] and meta-analyses [12,200,201] confirmed these results, there are a studies that have not found any relationship between BDNF and depression [202], or that provided evidence of positive correlation between BDNF and higher scores of scales for assessing depression in specific subgroups of patients [203]. Interestingly, genetic and epigenetic modifications in the BDNF gene have been associated to depressive disorders [204].

Similarly, alteration in circulating NGF levels have been detected in patients with depression. Clinical studies showed its reduced levels in patients with MDD compared to healthy control, and that NGF is negatively associated with depressive symptoms $[205,206]$. Nevertheless, in elderly patients this association seems to be attenuated [207].

As regard to NT-3 and 4/5 results are still controversial. Some studies found increased circulating levels of NT-3 [208,209], and NT-4/5 [209,210] in BD patients, while other studies demonstrated reduced $[189,211]$ or unchanged levels $[212,213]$.

\subsubsection{Neurotrophins and Platelets Function}

The impact of NTs on platelet function has not been well-investigated yet. To our knowledge, it is only known that NGF can bind platelet surface and induce aggregation [214], while no information is available on the effect of BDNF on platelet function, even though BDNF can bind a specific site on platelets surface with subsequent internalization [215]. Platelets contain both NGF and BDNF, 
that are spontaneously released upon platelet activation [215-219]. From data present in literature is conceivable that NGF and BDNF are not stored in the same granules and that their release is mediated by different mechanisms, even though these mechanisms are still poorly characterized [219].

In particular, NGF is released within $10 \mathrm{~min}$ under calcium-free conditions, while after $60 \mathrm{~min}$ in presence of calcium his release is significantly reduced [219]. This event is faster when platelets are co-incubated with ibuprofen, while indomethacin do not affect NGF release [219].

On the other hand, only a low amount BDNF, stored in the $\alpha$-granules [215], is released under calcium-free conditions, while calcium markedly increases its release. Ibuprofen and clopidogrel but not indomethacin and aspirin decrease its release $[219,220]$. Interestingly, when platelets are stimulated with thrombin, the mechanism of BDNF release is consequent to the activation of Protease-Activated receptor-1 (PAR-1). PAR-1 peptide induces a biphasic BDNF release, where only the first phase is calcium mobilization-dependent, as provided by its inhibition mediated by Prostaglandin-1 (PGE-1) pretreatment [217]. In this contest, authors demonstrated that BDNF is released by the fusion of $\alpha$-granules with the Open Canalicular System (OCS), forming the swollen OCS [217].

Interestingly, it has been shown that the amount of serum BDNF well reflect the amount of BDNF found in platelets [221]. In agreement with the decreased levels of BDNF under depression conditions [222,223], the platelet BDNF content is significantly reduced in patients with depression compared to control subjects [224], and the antidepressant pharmacotherapy normalize its levels. Then, it is possible to speculate that the platelet pre-activation state of MDD patients leads to their BDNF reservoir depletion [224], influencing negatively endothelial function and thrombus growing and stability $[154,164,166]$ (Figure 2).

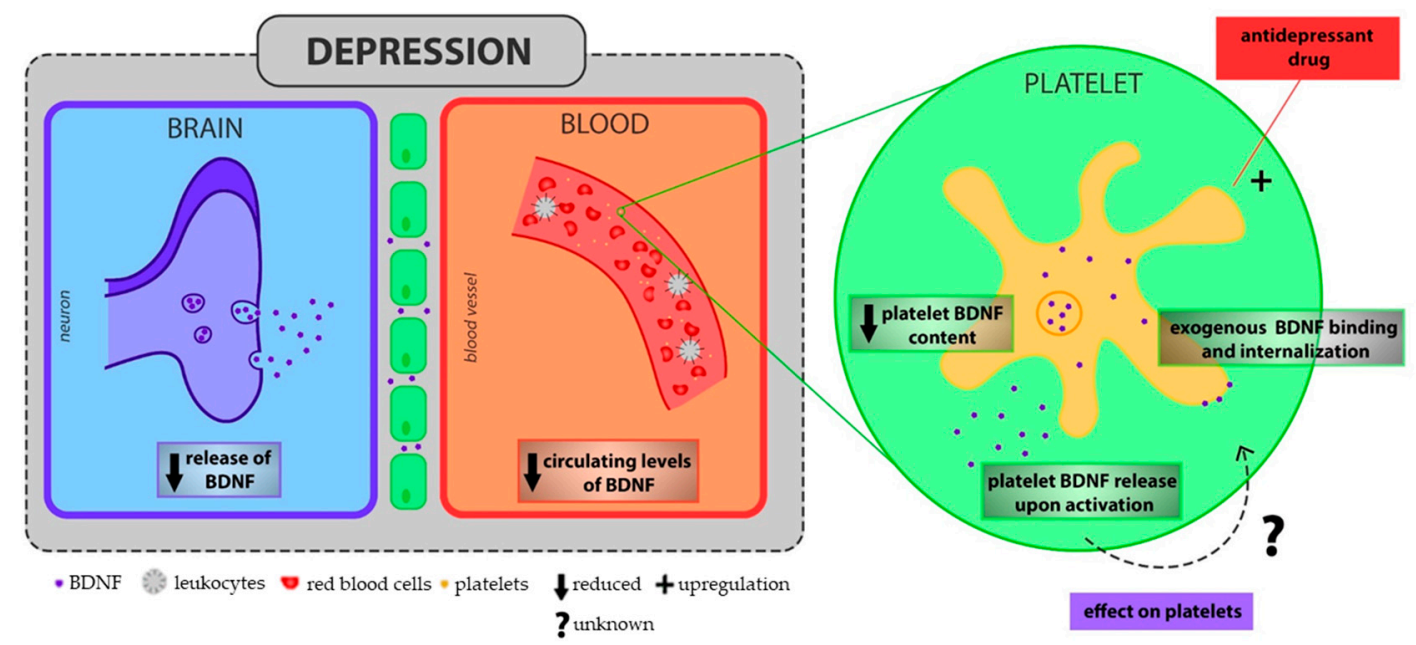

Figure 2. The controversial role of BDNF on platelet function. Depressed patients are characterized by the reduction of BDNF levels in the brain, that is well reflected by its decreased plasma and serum levels [221-223]. Remarkably, platelet BDNF content is reduced in depressed patients [224], but antidepressant treatment is able to restore their levels [224], indicating that a pre-activated state may promote platelet emptying of their BDNF reservoir. Platelets, when activated, can release BDNF $[154,215,217,218]$, and extracellular BDNF can bind a specific site on platelets surface with subsequent internalization [215]. However, there are no information about its possible effect on platelets. BDNF: Brain-derived Neurotrophic Factor.

The genetic knock-in mouse carrying BDNFVal66Met polymorphisms, that recapitulates the phenotypic hallmarks of human disease (e.g., depression and CVD) [179] has been a helpful model to investigate the relationship between this polymorphism and platelet function. Specifically, the presence of this polymorphism predisposes to platelet hyper-activated phenotype, enhancing P-selectin expression, GPIIb/IIIa receptor activity, ability to bind leukocytes and fibrinogen, and aggregation $[179,225]$. 


\section{Lipid Molecules and Lipoproteins}

Lipids are essential structural components of cell membranes and play a crucial role in different metabolic pathways and cellular functions [226]. Lipids alteration is associated with cardiovascular risk [70]. A rise in cholesterol concentration increases the risk for death by CVD [227], and low-density lipoprotein (LDL), contributing to the development of atherosclerotic plaques, are included among the traditional risk factors for thrombosis. LDL may be oxidized, entrapped in macrophages inducing their differentiation in foam cells, and they may also bind to proteoglycans in the arterial intima. In addition to the critical role of LDL, a reduction of high-density lipoproteins (HDL) may cooperate to promote atherosclerosis. HDL inhibits oxidation of LDL, removes cholesterol from foam cells and reduces inflammation $[228,229]$.

\subsection{Lipid, Low Density Lipoprotein and Lipids Peroxidation in Depression}

A large body of literature has provided knowledge on the relation between lipid status and psychotic disorders [230-232], whereas very few data is available on depression.

Nevertheless, a relation between depression and lipid disturbances has been recently demonstrated [233-240].

Actually, high total cholesterol (TC) and LDL are significantly associated with depressive symptoms and severity, with depression prospective course [236], and with metabolic syndrome in MDD [237]. In support of the relation between the severity of depression and cholesterol alteration, Enko et al. showed that, although depressed patients display only a slight increase in TC and LDL, there is a positive correlation between BDI-II depression score and triglycerides (TG), TC and LDL, and a negative, even though not significant, correlation with HDL [238]. In particular, an increase in LDL/HDL ratio has been observed in MDD patients $[235,239,240]$. By contrast, other studies showed that lower concentrations of TC and LDL were associated with MDD [241,242], and with incidence of depression [243-246], and that during first episodes of MDD higher TG levels and low HDL but similar LDL levels were found [247]. In addition, emerging data from a meta-analysis showed that depression was inversely associated with TC levels, and directly related to HDL levels, especially in women [235], whereas a U-shaped relationship with LDL was found [234]. The cross sectional nature of most studies, the different categorization of age, sampling and dissimilar tools of evaluation of depression applied in the studies, as well as the considerations of confounder factors (e.g., BMI, drug treatments) might explain the controversial findings about depression and circulating lipids and lipoproteins. Moreover, several studies analyzed the association of metabolic alterations with MDD, without carrying information about the inclusion of the BD individuals or without specifying which episode they were experiencing [237], all factors that could affect the conclusions.

Additionally to lipid molecules, the potential relationship with lipid peroxidation products as well as with oxidized LDL (oxLDL) and depression have to be considered [248].

The lipid peroxidation marker malondialdehyde (MDA) is increased in MDD patients compared to healthy control [249-252], and correlates with depression severity [253,254]. Similarly, the metabolites of F2 isoprostanes, an additional marker of lipid peroxidation, are greater in urine, plasma and serum of patients with depressive disturbances or MDD. This difference is particularly marked in elderly men [255], and is sex- and age-independent [256]. Only one study did not find significant difference between depressed and control subjects; however, this conclusion may be a result of the small sample size used [257].

Depressed patients have also higher levels of serum oxLDL antibodies than normal control [258], and a positive correlation emerged between serum oxLDL/LDL ratio with both Centre Epidemiological Studies Depression Scale (CES-D) score and perceived stress in a Japanese population [259]. Interestingly, depressed patients with great serum oxLDL antibodies are at high risk for atherosclerosis or have atherosclerotic lesions $[9,258]$, suggesting a relationship among depression, oxLDL and CVD. 
Overall, the positive association found between LDL or oxLDL and BMI [260,261], and between BMI and depressive symptoms [71], suggests that depression, directly or indirectly, leading to weight gain and to metabolic syndrome, could predispose to lipid alteration and to CVD.

\subsection{Low Density Lipoprotein, Lipids Peroxidation and Platelet Function}

Disorders in lipid status, above described, in patients with depression and CVD may contribute to platelets activation leading to acute thrombotic events.

LDL increases the sensitivity of blood platelets to agonist stimulation, making their response faster and more extensive [228]. Individuals with high plasma-LDL have hyper-reactive platelets and greater plasma levels of platelet activation markers, including BTG and soluble CD40 ligand (CD40L) [228]. In vitro, platelets exposed to LDL display hyper-aggregability, increased fibrinogen binding and surface-expression of P-selectin, and increased production of TX, and generation of Reactive Oxygen Species (ROS) [228,262].

Of note, oxLDL can influence platelet activation, apoptosis, and association with monocytes/macrophages [228]. In particular, by binding scavenger receptors on platelets (e.g., CD36) [228,263], oxLDL enhances NADPH oxidase-2 (NOX-2)-mediated generation of ROS and platelet hyper-reactivity [264], including platelet degranulation, GPaIIb3-integrin activation, apoptosis, thrombin generation, and shape change. Finally, LDL-oxLDL enhances platelet release of CXCL12 (Stromal Cell-derived Factor-1-SDF-1), that in turn prompts LDL-oxLDL uptake and synergistically augments the LDL-oxLDL-induced pro-oxidative and thrombogenic impact on platelet function [265].

\section{Reactive Oxygen Species}

ROS (i.e., superoxide anion $\left(\mathrm{O}_{2^{-}}\right)$, hydrogen peroxide $\left(\mathrm{H}_{2} \mathrm{O}_{2}\right)$, hydroxyl radical $(\bullet \mathrm{OH})$, hydroxyl ion $(\mathrm{OH}-)$ consist of radical and non-radical oxygen species formed by the partial reduction of oxygen [266]. ROS modulate several physiological processes, however when their excessive production is not counteracted by antioxidant capacity of human physiology there is imbalance in the redox system, resulting in tissue damage and in the development and progression of several diseases. The implication of ROS in the pathogenesis of CVDs and thrombosis has been well described [267]. Abnormal ROS increase has been observed in atherosclerosis [268], and in coronary artery disease (CAD) patients and associated with future CVD events [269]. The most well-known sources of ROS in the cardiovascular system are NOX family of enzymes, uncoupled endothelial nitric oxide synthase (eNOS), mitochondria and xanthine oxidase $(\mathrm{XO})$, whose function is critical in determining the onset and progression of CVD [270].

\subsection{Reactive Oxygen Species in Depression}

Clinical studies have reviewed the possible impact of oxidative stress in the pathophysiology of depression [271-274], focusing on ROS iper-production or on the activation of enzymes relevant in pro/antioxidant processes [e.g., NOX, XO, superoxide dismutase (SOD) and catalase (CAT)] [274], and experimental models have established that the enhanced ROS production favors depression-like phenotype [275].

Several peripheral markers of oxidative stress and mechanisms implicated in redox balance are altered in MDD, nevertheless, there is a significant heterogeneity across the studies [276], specifically as regard to ROS alteration [277], hence importance of careful phenotyping of the depressed and control subjects.

Decreased SOD activity $[253,278]$ in red blood cells (RBC) of depressed patients have been measured in first [253], recurrent [251], and bipolar episodes [279] suggesting also a connection with different subtypes of depressive manifestations.

The reduction of SOD activity associated with increased XO activity [278] and unchanged CAT activity $[253,276]$ well explain the increased ROS generation detected in patients with depression [252, 276]. However, other studies showed increased RBC SOD activity $[249,250,252]$, that is potentially 
explained as a protective mechanism induced by organism to counterbalance oxidative stress that occurs during depressive disorders (Figure 3 ).

A recent meta-analysis indicated that depression is associated with enhanced oxidative damage, as provided by increased urinary and serum/plasma levels of 8-hidroxy-2'-deoxyguanosine (8-OHdG) and F2-isoprostanes [273] (Figure 3).

Noteworthy is that mitochondrial dysfunction is considered the preferential mechanism as source of ROS in MDD [280,281]; indeed, reduced mitochondrial function is implicated in depression onset and progression [281]. This finding is relevant since the brain is a highly active organ with high energy consumption, and then it is more susceptible to the deleterious effect of excessive ROS production related to mitochondrial dysfunctions.

Overall, the imbalance of redox system, with an increased production of ROS, that characterizes depression disorders may cover a key role in promoting platelets activation.

\subsection{Reactive Oxygen Species and Platelet Function}

Extracellular ROS promote the activation of GPIIb/IIIa interacting with thiol groups in the extracellular domain, and the shedding of GPVI and GPIb $\alpha$ through a mechanism mediated by A Disintegrin and Metalloproteases (ADAM) [282,283]. These events have been recently associated with increased coagulation factor binding and enhanced thrombin and fibrin generation, favoring a pro-coagulant phenotype of platelets [284]. Activated platelets, via NOX, cyclooxygenases, eNOS, $\mathrm{XO}$, and mitochondrial respiration $[285,286]$, are able to generate per se ROS, that in turn re-activate platelets [287,288], especially in older patients [289]. As consequence, intra-platelets ROS support platelet activation promoting $\alpha$-granule exocytosis [290], increasing the sensitivity of platelets receptor like GPIIb/IIIa, GPIb $\alpha$ and GPVI [291,292]. When platelets are exposed to thrombin-or collagen ROS act as second messenger [293], inducing calcium mobilization [293], upregulating CD40L surface expression and release [294], and generating isoprostanes including 8-iso-prostaglandin F2 $\alpha$ (PGF2 $\alpha$ ) that can promote platelet aggregation via TX receptor in the presence of low concentrations of other agonists [295-297] (Figure 3).

Interestingly, alteration in platelets mitochondrial bioenergetics has been detected in MDD patients compared to a matched control subjects [298,299], supporting the hypothesis of interplay among ROS, platelet activation and depression.

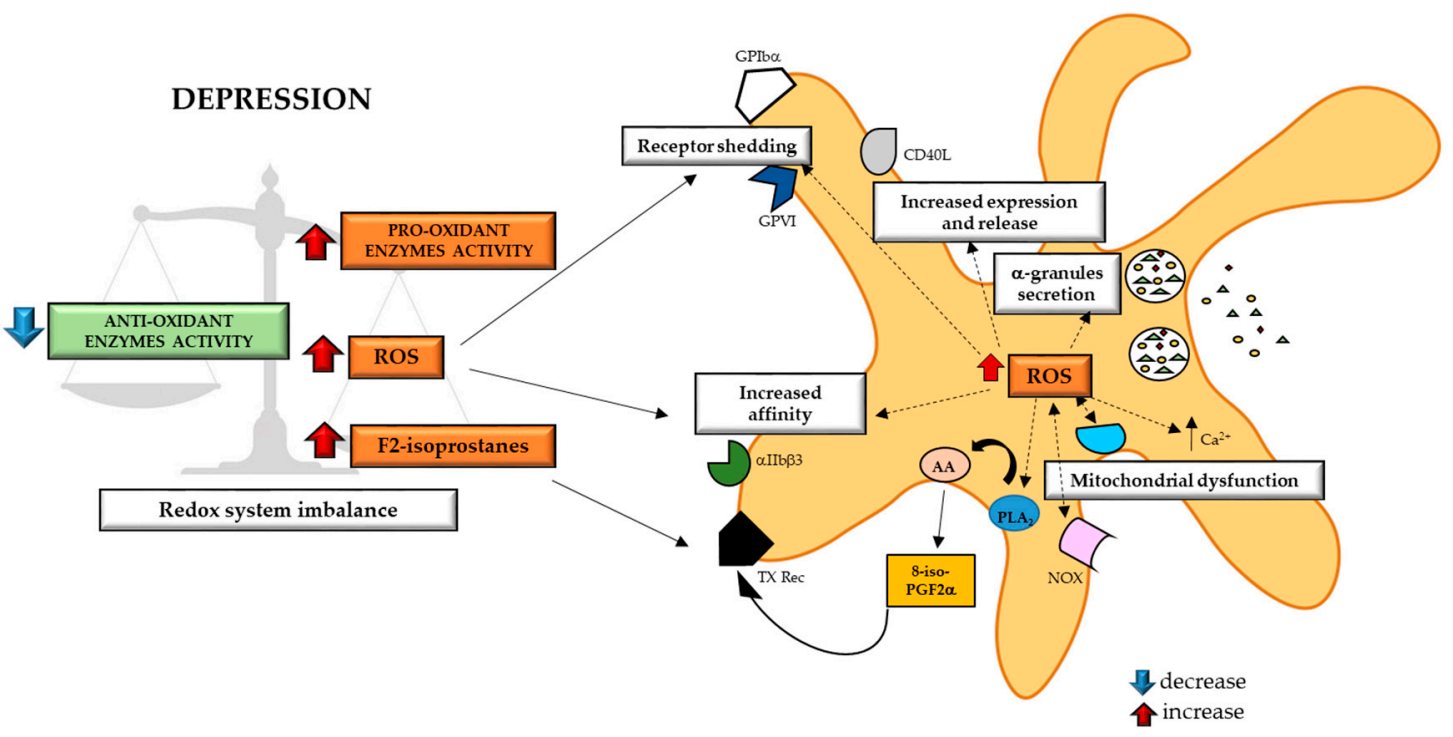

Figure 3. Increased oxidative stress that occurs during major depressive disorders (MDD), can activate platelets. Depressed patients are characterized by an imbalance in redox system with increased pro-oxidant enzyme activity not counterbalanced by anti-oxidant enzyme [251-253,276,278,279]. This imbalance promotes an excessive production of ROS and an increase in F2 isoprostanes circulating 
levels. Extracellular ROS is then able to activate platelets increasing GPIIb/IIIa receptor affinity, and inducing GPI $\alpha$ and GPVI receptors shedding with consequent activation of downstream pathways [282,283]. In the same time, the activation of platelets due to pro-oxidant environment favors intra-platelets production of ROS. Intra-platelets ROS support platelet activation promoting $\alpha$-granule exocytosis, increasing the sensitivity of platelet receptors, acting as second messenger in thrombin- or collagen-activated platelets, inducing calcium mobilization, upregulating CD40L surface expression and release and generating isoprostanes, including 8-iso-PGF2 $\alpha$ [activating AA metabolism] [290-294]. PGF2 $\alpha$ can in turn activates TX receptor beyond supporting platelet activation [295-297]. Finally, the redox imbalance is furtherly fed by a vicious cycle of ROS production due to activation of NOX enzyme [285-289] and to alteration of platelet mitochondrial function [298,299]. ROS: Reactive Oxygen Species; GP: glycoprotein; CD40L: CD40 Ligand; $\mathrm{Ca}^{2+}$ : Calcium; NOX: NADPH oxidase; PLA $_{2}$ : Phospholipase $\mathrm{A}_{2} ; \mathrm{AA}$ : Arachidonic Acid; TX: Thromboxane.

\section{Inflammatory Factors}

Inflammatory process has been extensively described in worsening CVD prognosis, and platelets are recognized as active mediators of this mechanisms [300]. The pro-inflammatory status has been also associated with MDD and is exhaustively described in literature. In particular, pro-inflammatory cytokines like interleukin-2 (IL-2), IL-6, soluble IL-6 receptor, tumor necrosis factor- $\alpha$ (TNF- $\alpha$ ) and interferon- $\gamma$ (IFN- $\gamma$ ) are increased while anti-inflammatory cytokines like IL-4 and IL-10 are decreased during depressive disorders [301]. More recent studies demonstrated that also chemokines contribute to neurobiological processes relevant to psychiatric disorders [302], suggesting another point of connection between depression and cardiovascular disease.

\subsection{Chemokines}

Chemokines are small (8-12 kDa) chemotactic cytokines, which have an important role in directing the migration of blood cells to target tissues. Chemokines are classified into 4 groups, with the CC- and CXC-types being the most common [303]. Alteration in circulating levels of chemokines like CXCL8 (IL-8), CCL2 (Monocyte Chemoattractant Protein-1 (MCP-1), CCL26 (Eosinophil Chemotactic Protein-3 (Eotaxin-3), CCL5 (Regulated on Activation of Normal T cell-expressed and secreted (RANTES) entities) CXCL10 ( $\gamma$-Interferon-inducible Protein-10 (IP-10) or of chemokines receptors (e.g., fractalkine receptor-CX $\mathrm{C}_{3} \mathrm{CR} 1$ ) are associated with subclinical or proclaimed cardiovascular pathology (e.g., $\mathrm{MI}$, CAD, atherosclerosis) or with cardiovascular death [304-306]. In addition, it has been showed that the fractalkine receptor $\mathrm{CX}_{3} \mathrm{CR} 1$ plays a key role in atherosclerosis [305], and that a polymorphism in its gene is associated with a reduced risk for CAD [306].

Overall, chemokines represent a promising therapeutic target in cardiovascular disease [303], and recently have been also related to depression disorders [307].

\subsubsection{Chemokines in Depression}

Several studies highlighted the link between depressive symptoms and elevated circulating levels of chemokines, and the main results obtained are summarized in a recent review [307].

Higher blood levels of CCL11 (Eotaxin-1), RANTES, SDF-1 and $\mathrm{CXC}_{3} \mathrm{~L} 1$ (fractalkine) were found in depressed patients compared to controls [308-311] (Table 2).

In particular, Ogłodek et al. showed that RANTES and CXCL12 levels were significantly increased in both women and men with depressive disorders and that a relation between circulating levels of these chemokines and severity of depressive symptoms exists [309]. By contrast, Leighton et al., in a meta-analysis including 7 studies, did not find significant difference in circulating levels of RANTES and CCL3 (Macrophage Inflammatory Protein-1 $\alpha$ (MIP- $1 \alpha$ ) between MDD patients and control group [307] (Table 2). However, need to be mentioned that the conclusion of Leighton et al. may be incorrect due to the inclusion of studies that evaluated indiscriminately the RANTES levels in plasma, serum and whole blood of depressed patients (Table 2). Indeed, it has been reported that depressed 
patients have reduced serum levels of RANTES [308] and antidepressant treatment can restore its levels [311]. Nevertheless, reduced RANTES serum levels in depressed patients may be related to the activated platelet phenotype, that leads to the emptying of RANTES platelet reservoir [312].

Increased plasma levels of fractalkine in moderate-severe depressed patients compared to control subjects was found [313] and this result was confirmed by other studies, in which a correlation between fractalkine plasma levels and the severity of depressive symptoms was identified $[314,315]$ (Table 2). However, considering the scarcity of information about circulating levels of fractalkine in association with depression, further studies are needed, also taking into account the possible confounding factors (e.g., age, BMI) and the heterogeneity of MDD.

Instead, CCL4 (MIP-1 $\beta$ ) has been found lower in the serum of depressed patients compared to not depressed ones [307].

Finally, MCP-1 levels are usually higher in depressed patients compared to controls [302,310, $311,316,317]$, with the exception of some works [131,318] (Table 2). The careful analyses of these works highlighted that patient groups are highly heterogeneous, including different subgroups of depressed patients, e.g., patients with bipolar disturbs [316], obsessive-convulsive disorders [319], exhaustion [320], and nocturnal disturbs [321], leading to find no difference, almost in all cases, in circulating levels of MCP-1. Indeed, it is showed that MDD patients with suicidal ideation have surprisingly reduced levels of this chemokine [308].

In conclusion, the studies investigating the relationship between chemokines and depression are still few and often controversial, more research is needed to define whether their circulating levels are really enhanced in depression.

\subsubsection{Chemokines and Platelet Function}

The presence of chemokine receptors on the surface of platelets has been controversial for a long time, but now accumulated evidence show that CXCR4, CCR4, $\mathrm{CX}_{3} \mathrm{CR} 1$ and lower but still functional amounts of CCR1 and CCR3 are present on platelets [322-325].

As regard of chemokines whose levels result altered in MDD, only few were investigated in relation to platelets function. Nevertheless, some of them (e.g., MCP-1, Eotaxin-1, SDF-1 and fractalkine) are promising mediators of the link between depression and platelets activation.

It has been demonstrated that the activation of CCR1, 3 and 4 receptors by specific chemokines, including MCP-1, MIP-1 $\alpha$, Eotaxin, and RANTES, induces platelet aggregation and release of platelet granule contents [325] (Table 2).

In addition, fractalkine, through the activation of $\mathrm{CX}_{3} \mathrm{CR} 1$, promotes adhesion of platelets on fibrinogen and collagen [326], and induces not only monocyte recruitment but also platelet accumulation at sites of arterial injury [327]. It has been recently demonstrated that also GPIb can acts as a fractalkine receptor [328], thus suggesting another possible target in regulating platelets activation. Interestingly, a positive correlation between levels of fractalkine and platelet activation in patients with CVD was identified [326] (Table 2).

Finally, SDF-1, expressed on both megakaryocytes and platelets [322], modulates megakaryocytes maturation and megakaryocytopoiesis [329], induces platelets activation, enhancing platelet aggregation and intra-platelet $\mathrm{Ca}^{2+}$ flux, and it modulates the expression of CXCR4-CXCR7 receptors on platelets surface [330]. Of note, the expression of CXCR4-CXCR7 receptors on platelets have a prognostic value in CVD [330] (Table 2). 
Table 2. Chemokines potentially relevant in the relationship between depression and platelet activation.

\begin{tabular}{|c|c|c|c|c|}
\hline \multicolumn{3}{|c|}{ DEPRESSION } & \multicolumn{2}{|r|}{$\underline{\text { PLATELETS }}$} \\
\hline Chemokines & District & Levels & Receptor & Effect \\
\hline MCP-1 & $\begin{array}{l}\text { Serum } \\
\text { Plasma }\end{array}$ & $\begin{array}{c}\uparrow[302,310,311, \\
316,317]\end{array}$ & CCR1/CCR3 & $\begin{array}{c}\text { Platelet aggregation [325] } \\
\text { Granules content release [325] }\end{array}$ \\
\hline Eotaxin-1 & Serum & $\uparrow[308,310]$ & CCR1/CCR3 & $\begin{array}{c}\text { Platelet aggregation [325] } \\
\text { Granules content release [325] }\end{array}$ \\
\hline RANTES & $\begin{array}{l}\text { Serum } \\
\text { Plasma }\end{array}$ & $\begin{array}{c}\downarrow[307,308,311] \\
\uparrow /=[307,309]\end{array}$ & CCR1/CCR3 & $\begin{array}{c}\text { Platelet aggregation [325] } \\
\text { Granules content release [325] }\end{array}$ \\
\hline SDF-1 & Plasma & $\uparrow[309]$ & CXCR4 & $\begin{array}{l}\text { Megakaryocytes maturation and } \\
\text { megakaryopoiesis [329] } \\
\text { Platelets activation, aggregation } \\
\text { and } \mathrm{Ca}^{2+} \text { flux [330] } \\
\text { Expression of platelets surface } \\
\text { expression of CXCR4-CXCR7 } \\
\text { receptors [330] }\end{array}$ \\
\hline MIP-1 $\alpha$ & Plasma & $=[307,311]$ & CCR1/CCR3 & $\begin{array}{c}\text { Platelet aggregation [325] } \\
\text { Granules content release [325] }\end{array}$ \\
\hline MIP-1 $\beta$ & Serum & $\downarrow[307]$ & CCR1/CCR3 & NA \\
\hline Fractalkine & Plasma & $\uparrow[313-315]$ & $\mathrm{CXC}_{3} \mathrm{CR} 1$ & $\begin{array}{c}\text { Platelet adhesion [326] } \\
\text { Platelet accumulation and } \\
\text { monocytes recruitment at injury } \\
\text { site [327] } \\
\text { Platelet activation in CVD patients } \\
\text { [326] }\end{array}$ \\
\hline
\end{tabular}

$\uparrow$ : increased, $\downarrow$ : decreased; =: similar levels compared to control. MCP1: Monocyte Chemoattractant Protein-1; Eotaxin-1: Eosinophil Chemotactic Protein-1; RANTES: Regulated on Activation of Normal T cell-expressed and secreted; SDF-1: Stromal Cell-derived Factor-1; MIP-1 $\alpha / \beta$ : Macrophage Inflammatory Protein- $1 \alpha / \beta$.

Interestingly, platelets store and release several chemokines [331] that influence both physiological and pathological conditions [332]. To our knowledge, the relationship among chemokines platelet-released, depression and CVD has not been investigated as yet. Nevertheless, we can hypothesize that chemokines released by hyper-reactive platelets contribute to progression of both depression and CVD, worsening the clinical outcome.

\section{Conclusions}

In spite of the provided evidence about highest prevalence of CVD in patients with depression, the molecular mechanisms at the basis of this relation are largely unknown. The hyper-activated response of platelets of depressed patients suggest them as possible and interesting mediators in this contest.

In this review we critically analyzed some of the molecules, whose alteration is relevant in promoting the onset of CVD and that are known or potentially associated with platelets activation and de-/activation, in depressive disorders. Even if many of the studies taken into consideration seem to suggest that circulating levels of these molecules are changed during depression, consequently favoring platelets activation, the results present in literature are often still controversial and need further investigation to give a univocal indication. In this perspective, it will be useful to study the pathways activated by these molecules in platelets of depressed patients to have an exhaustive insight about this subject matter and to understand molecular mechanisms underlying the link among depression, platelet activation and CVD. 
Author Contributions: Conceptualization, S.S.B. and P.A.; writing-original draft preparation, P.A. and S.S.B.; writing-review and editing, L.S., M.Z. and A.I.; funding acquisition, S.S.B. All authors have read and agreed to the published version of the manuscript.

Funding: This work was supported by funding from the Italian Ministry of Health, Rome, Italy (Ricerca Corrente RC 2019 MPP 2B ID 2755316, RC 2020 MPP 2B ID 2757640, and $5 \times 1000$ 2016-2018) and Fondazione Cariplo (Rif. 2018-0525).

Conflicts of Interest: The authors declare no conflict of interest.

\section{Abbreviations}

\begin{tabular}{|c|c|}
\hline $5-\mathrm{HT}$ & 5-Hydroxytriptamine \\
\hline 5-HT2 & 5-HT receptor \\
\hline 8 -isoPGF $2 \alpha$ & 8-iso-prostaglandin F2 $\alpha$ \\
\hline OHdG & 8-hydroxy-2'-deoxyguanosine \\
\hline ACS & Acute Coronary Syndrome \\
\hline ADAM & A Disintegrin and Metalloproteases \\
\hline ADP & Adenosine Diphosphate \\
\hline $\mathrm{AR}$ & Adrenergic Receptor \\
\hline $\mathrm{BD}$ & Bipolar Depression \\
\hline BDNF & Brain-derived Neurotrophic Factor \\
\hline BMI & Body Mass Index \\
\hline BTG & $\beta$-thromboglobulin \\
\hline CAD & Coronary Artery Disease \\
\hline cAMP & 3'-5'-Cyclic Adenosine Monophosphate \\
\hline CAT & Catalase \\
\hline CD40L & CD40 Ligand \\
\hline CES-D & Centre Epidemiological Studies Depression Scale \\
\hline CHD & Coronary Heart Disease \\
\hline CRP & C-Reactive Protein \\
\hline CVD & Cardiovascular Disease \\
\hline $\mathrm{CXC}_{3} \mathrm{~L} 1$ & Fractalkine \\
\hline $\mathrm{CXC}_{3} \mathrm{R} 1$ & Fractalkine Receptor \\
\hline DA & Dopamine \\
\hline eNOS & Endothelial Nitric Oxide Synthase \\
\hline EPI & Epinephrine \\
\hline Eotaxin & Eosinophil Chemotactic Protein \\
\hline G protein & Guanine nucleotide-binding proteins \\
\hline GP & Glycoprotein \\
\hline HAM-D & Hamilton Depression Rating Scale \\
\hline HDL & High-Density Lipoprotein \\
\hline $\mathrm{HF}$ & Heart Failure \\
\hline HPA & Hypothalamic-Pituitary-Adrenal \\
\hline IFN- $\gamma$ & Interferon- $\gamma$ \\
\hline IL & Interleukin \\
\hline IP-10 & $\gamma$-Interferon-inducible Protein-10 \\
\hline IRS-1 & Insulin Receptor Substrate-1 \\
\hline JAK2 & Janus Kinase 2 \\
\hline LepRb & Leptin Receptor \\
\hline LEPRL & Long form of Leptin Receptor \\
\hline LDL & Low-Density Lipoprotein \\
\hline MCP-1 & Monocyte Chemoattractant Protein-1 \\
\hline MDA & Malondialdheyde \\
\hline MDD & Major Depressive Disorders \\
\hline MI & Myocardial Infarction \\
\hline $\mathrm{MIP}-1 \alpha / \beta$ & Macrophage Inflammatory Protein $-1 \alpha / \beta$ \\
\hline
\end{tabular}




$\begin{array}{ll}\text { NE } & \text { Norepinephrine } \\ \text { NGF } & \text { Nerve Growth Factor } \\ \text { NOX } & \text { NADPH oxidase } \\ \text { NT } & \text { Neurotrophin } \\ \text { OCS } & \text { Open Canalicular System } \\ \text { oxLDL } & \text { Oxidized LDL } \\ \text { PAR-1 } & \text { Protease-Activated Receptor-1 } \\ \text { PDE3A } & \text { Phosphodiesterase 3A } \\ \text { PF4 } & \text { Platelet Factor 4 } \\ \text { PGE-1 } & \text { Prostagladin E-1 } \\ \text { PLA/C } & \text { Phospholipase A/C } \\ \text { PI3K } & \text { Phosphatidylinositol 3-Kinase } \\ \text { PK } & \text { Protein Kinase } \\ \text { PMN } & \text { Polymorphonuclear } \\ \text { RANTES } & \text { Regulated on Activation of Normal T cell-expressed and secreted } \\ \text { RBC } & \text { Red Blood Cells } \\ \text { ROS } & \text { Reactive Oxygen Species } \\ \text { SDF-1 } & \text { Stromal Cell-derived Factor-1 } \\ \text { SOD } & \text { Superoxide dismutase } \\ \text { TC } & \text { Total Cholesterol } \\ \text { TF } & \text { Tissue Factor } \\ \text { TG } & \text { Triglycerides } \\ \text { TNF- } \alpha & \text { Tumor Necrosis Factor- } \alpha \\ \text { TrkB } & \text { Tropomyosin receptor kinase B } \\ \text { TX } & \text { Thromboxane } \\ \text { vWF } & \text { Von Willebrand Factor } \\ \text { XO } & \text { Xantine oxidase }\end{array}$

\section{References}

1. Van Der Kooy, K.; Van Hout, H.; Marwijk, H.; Marten, H.; Stehouwer, C.; Beekman, A. Depression and the risk for cardiovascular diseases: Systematic review and meta analysis. Int. J. Geriatr. Psychiatry 2007, 22, 613-626. [CrossRef]

2. Batelaan, N.M.; Seldenrijk, A.; Bot, M.; Van Balkom, A.J.L.M.; Penninx, B.W.J.H. Anxiety and new onset of cardiovascular disease: Critical review and meta-analysis. Br. J. Psychiatry 2016, 208, 223-231. [CrossRef] [PubMed]

3. Carney, R.M.; Freedland, K.E. Depression and coronary heart disease. Nat. Rev. Cardiol. 2016, 14, 145-155. [CrossRef] [PubMed]

4. Gan, Y.; Gong, Y.; Tong, X.; Sun, H.; Cong, Y.; Dong, X.; Wang, Y.; Xu, X.; Yin, X.; Deng, J.; et al. Depression and the risk of coronary heart disease: A meta-analysis of prospective cohort studies. BMC Psychiatry 2014, 14, 371. [CrossRef] [PubMed]

5. McCabe, P.J. Psychological Distress in Patients Diagnosed with Atrial Fibrillation. J. Cardiovasc. Nurs. 2010, 25, 40-51. [CrossRef]

6. Rothe, A.V.E.; Hutt, F.; Baumert, J.; Breithardt, G.; Egoette, A.; Kirchhof, P.; Ladwig, K.-H. Depressed mood amplifies heart-related symptoms in persistent and paroxysmal atrial fibrillation patients: A longitudinal analysis-data from the German Competence Network on Atrial Fibrillation. Europace 2015, 17, 1354-1362. [CrossRef]

7. Lichtman, J.H.; Froelicher, E.S.; Blumenthal, J.A.; Carney, R.M.; Doering, L.V.; Frasure-Smith, N.; Freedland, K.E.; Jaffe, A.S.; Leifheit-Limson, E.C.; Sheps, D.S.; et al. Depression as a Risk Factor for Poor Prognosis Among Patients with Acute Coronary Syndrome: Systematic Review and Recommendations. Circulation 2014, 129, 1350-1369. [CrossRef]

8. Hare, D.L.; Toukhsati, S.R.; Johansson, P.; Jaarsma, T. Depression and cardiovascular disease: A clinical review. Eur. Hear. J. 2013, 35, 1365-1372. [CrossRef] 
9. Maes, M.; Ruckoanich, P.; Chang, Y.S.; Mahanonda, N.; Berk, M. Multiple aberrations in shared inflammatory and oxidative \& nitrosative stress (IO\&NS) pathways explain the co-association of depression and cardiovascular disorder (CVD), and the increased risk for CVD and due mortality in depressed patients. Prog. Neuro-Psychopharmacol. Biol. Psychiatry 2011, 35, 769-783. [CrossRef]

10. Everson-Rose, S.A.; Lewis, T.T. Psychosocial factors and cardiovascular diseases. Annu. Rev. Public Health 2005, 26, 469-500. [CrossRef]

11. Castrén, E.; Voikar, V.; Rantamäki, T. Role of neurotrophic factors in depression. Curr. Opin. Pharmacol. 2007, 7, 18-21. [CrossRef] [PubMed]

12. Brunoni, A.R.; Lopes, M.; Fregni, F. A systematic review and meta-analysis of clinical studies on major depression and BDNF levels: Implications for the role of neuroplasticity in depression. Int. J. Neuropsychopharmacol. 2008, 11, 1169-1180. [CrossRef] [PubMed]

13. Canobbio, I. Blood platelets: Circulating mirrors of neurons? Res. Pract. Thromb Haemost. 2019, 3, 564-565. [CrossRef] [PubMed]

14. Goubau, C.; Buyse, G.M.; Di Michele, M.; Van Geet, C.; Freson, K. Regulated granule trafficking in platelets and neurons: A common molecular machinery. Eur. J. Paediatr. Neurol. 2013, 17, 117-125. [CrossRef]

15. Canobbio, I.; Guidetti, G.F.; Torti, M. Platelets in Neurological Disorders. In Platelets in Thrombotic and Non-Thrombotic Disorders: Pathophysiology, Pharmacology and Therapeutics: An Update; Gresele, P., Kleiman, N.S., Lopez, J.A., Page, C.P., Eds.; Springer International Publishing: Cham, Switzerland, 2017; pp. 513-530. [CrossRef]

16. Tseng, W.-L.; Chen, T.-H.; Huang, C.-C.; Huang, Y.-H.; Yeh, C.-F.; Tsai, H.-J.; Lee, H.-Y.; Kao, C.-Y.; Lin, S.-W.; Liao, H.-R.; et al. Impaired thrombin generation in Reelin-deficient mice: A potential role of plasma Reelin in hemostasis. J. Thromb. Haemost. 2014, 12, 2054-2064. [CrossRef]

17. Van Nostrand, W.E.; Schmaier, A.H.; Farrow, J.S.; Cunningham, D.D. Protease nexin-II (amyloid beta-protein precursor): A platelet alpha-granule protein. Science 1990, 248, 745-748. [CrossRef]

18. Canobbio, I.; Guidetti, G.F.; Oliviero, B.; Manganaro, D.; Vara, D.; Torti, M.; Pula, G. Amyloid $\beta$-peptide-dependent activation of human platelets: Essential role for $\mathrm{Ca} 2+$ and ADP in aggregation and thrombus formation. Biochem. J. 2014, 462, 513-523. [CrossRef]

19. Canobbio, I.; Visconte, C.; Momi, S.; Retta, S.F.; Zarà, M.; Canino, J.; Falcinelli, E.; Gresele, P.; Torti, M. Platelet amyloid precursor protein is a modulator of venous thromboembolism in mice. Blood 2017, 130, 527-536. [CrossRef]

20. Chacón-Fernández, P.; Säuberli, K.; Colzani, M.; Moreau, T.; Ghevaert, C.; Barde, Y.-A. Brain-derived Neurotrophic Factor in Megakaryocytes. J. Biol. Chem. 2016, 291, 9872-9881. [CrossRef]

21. Gabriele, S.; Sacco, R.; Persico, A.M. Blood serotonin levels in autism spectrum disorder: A systematic review and meta-analysis. Eur. Neuropsychopharmacol. 2014, 24, 919-929. [CrossRef]

22. Musselman, D.L.; Tomer, A.; Manatunga, A.K.; Knight, B.T.; Porter, M.R.; Kasey, S.; Marzec, U.; Harker, L.A.; Nemeroff, C.B. Exaggerated platelet reactivity in major depression. Am. J. Psychiatry 1996, 153, 1313-1317. [CrossRef] [PubMed]

23. Markovitz, J.H.; Matthews, K.A. Platelets and coronary heart disease: Potential psychophysiologic mechanisms. Psychosom. Med. 1991, 53, 643-668. [CrossRef] [PubMed]

24. Markovitz, J.H.; Shuster, J.L.; Chitwood, W.S.; May, R.S.; Tolbert, L.C. Platelet Activation in Depression and Effects of Sertraline Treatment: An Open-Label Study. Am. J. Psychiatry 2000, 157, 1006-1008. [CrossRef] [PubMed]

25. Morel-Kopp, M.-C.; McLean, L.; Chen, Q.; Tofler, G.H.; Tennant, C.; Maddison, V.; Ward, C.M. The association of depression with platelet activation: Evidence for a treatment effect. J. Thromb. Haemost. 2009, 7, 573-581. [CrossRef] [PubMed]

26. Walsh, M.-T.; Dinan, T.G.; Condren, R.M.; Ryan, M.; Kenny, D. Depression is associated with an increase in the expression of the platelet adhesion receptor glycoprotein Ib. Life Sci. 2002, 70, 3155-3165. [CrossRef]

27. Musselman, D.L.; Marzec, U.M.; Manatunga, A.; Penna, S.; Reemsnyder, A.; Knight, B.T.; Baron, A.; Hanson, S.R.; Nemeroff, C.B. Platelet Reactivity in Depressed Patients Treated with Paroxetine. Arch. Gen. Psychiatry 2000, 57, 875-882. [CrossRef] [PubMed]

28. Williams, M.S. Platelets and depression in cardiovascular disease: A brief review of the current literature. World J. Psychiatry 2012, 2, 114-123. [CrossRef] 
29. Steiner, M. Serotonin, depression, and cardiovascular disease: Sex-specific issues. Acta Physiol. 2011, 203, 253-258. [CrossRef]

30. Zhuang, X.; Xu, H.; Fang, Z.; Xu, C.; Xue, C.; Hong, X. Platelet serotonin and serotonin transporter as peripheral surrogates in depression and anxiety patients. Eur. J. Pharmacol. 2018, 834, 213-220. [CrossRef]

31. Shimbo, D.; Child, J.; Davidson, K.; Geer, E.; Osende, J.I.; Reddy, S.; Dronge, A.; Fuster, V.; Badimon, J.J. Exaggerated serotonin-mediated platelet reactivity as a possible link in depression and acute coronary syndromes. Am. J. Cardiol. 2002, 89, 331-333. [CrossRef]

32. McAdams, C.; Leonard, B.E. Changes in platelet aggregatory responses to collagen and 5-hydroxytryptamine in depressed, schizophrenic and manic patients. Int. Clin. Psychopharmacol. 1992, 7, 81-85. [PubMed]

33. Eckert, A.; Gaan, H.; Riemann, D.; Aldenhoff, J.; Müller, W. Elevated intracellular calcium levels after 5-HT2 receptor stimulation in platelets of depressed patients. Biol. Psychiatry 1993, 34, 565-568. [CrossRef]

34. Oliver, K.H.; Duvernay, M.T.; Hamm, H.E.; Carneiro, A.M.D. Loss of Serotonin Transporter Function Alters ADP-mediated Glycoprotein $\alpha \mathrm{IIb} \beta 3$ Activation through Dysregulation of the 5-HT2AReceptor. J. Biol. Chem. 2016, 291, 20210-20219. [CrossRef] [PubMed]

35. Pandey, G.N.; Pandey, S.C.; Janicak, P.G.; Marks, R.C.; Davis, J.M. Platelet serotonin-2 receptor binding sites in depression and suicide. Biol. Psychiatry 1990, 28, 215-222. [CrossRef]

36. Hrdina, P.D.; Bakish, D.; Chudzik, J.; Ravindran, A.; Lapierre, Y.D. Serotonergic markers in platelets of patients with major depression: Upregulation of 5-HT2 receptors. J. Psychiatry Neurosci. 1995, 20, 11-19.

37. Motiejunaite, J.; Amar, L.; Vidal-Petiot, E. Adrenergic receptors and cardiovascular effects of catecholamines. Ann. d'Endocrinol. 2020. [CrossRef]

38. Tank, A.W.; Wong, D.L. Peripheral and Central Effects of Circulating Catecholamines. Compr. Physiol. 2014, 5, 1-15. [CrossRef]

39. Raab, W. Key position of catecholamines in functional and degenerative cardiovascular pathology*. Am. J. Cardiol. 1960, 5, 571-578. [CrossRef]

40. Ali, D.C.; Zhou, X.; Gordon, A.; Majeed, F.; Saeed, M.; Ogbuke, M.I.; Atif, M.; Zubair, H.M.; Changxing, L. $\beta$-Adrenergic receptor, an essential target in cardiovascular diseases. Hear. Fail. Rev. 2019, 25, 343-354. [CrossRef]

41. Bucolo, C.; Leggio, G.M.; Drago, F.; Salomone, S. Dopamine outside the brain: The eye, cardiovascular system and endocrine pancreas. Pharmacol. Ther. 2019, 203, 107392. [CrossRef]

42. Stanford, S.C.; Heal, D.J. Catecholamines: Knowledge and understanding in the 1960s, now, and in the future. Brain Neurosci. Adv. 2019, 3, 2398212818810682. [CrossRef] [PubMed]

43. Ordway, G.; Schenk, J.; Stockmeier, C.; May, W.; Klimek, V. Elevated agonist binding to $\alpha 2$-adrenoceptors in the locus coeruleus in major depression. Biol. Psychiatry 2003, 53, 315-323. [CrossRef]

44. Valdizán, E.M.; Díez-Alarcia, R.; González-Maeso, J.; Pilar-Cuéllar, F.; García-Sevilla, J.A.; Meana, J.J.; Pazos, A. $\alpha_{2}$-Adrenoceptor functionality in postmortem frontal cortex of depressed suicide victims. Biol. Psychiatry 2010, 68, 869-872. [CrossRef] [PubMed]

45. Pecina, M.; Sikora, M.; Avery, E.T.; Heffernan, J.; Peciña, S.; Mickey, B.J.; Zubieta, J.-K. Striatal dopamine $\mathrm{D} 2 / 3$ receptor-mediated neurotransmission in major depression: Implications for anhedonia, anxiety and treatment response. Eur. Neuropsychopharmacol. 2017, 27, 977-986. [CrossRef]

46. Grace, A.A. Dysregulation of the dopamine system in the pathophysiology of schizophrenia and depression. Nat. Rev. Neurosci. 2016, 17, 524-532. [CrossRef]

47. Lake, C.R.; Pickar, D.; Ziegler, M.G.; Lipper, S.; Slater, S.; Murphy, D.L. High plasma norepinephrine levels in patients with major affective disorder. Am. J. Psychiatry 1982, 139, 1315-1318. [CrossRef]

48. Wyatt, R.J.; Portnoy, B.; Kupfer, D.J.; Snyder, F.; Engelman, K. Resting Plasma Catecholamine Concentrations in Patients with Depression and Anxiety. Arch. Gen. Psychiatry 1971, 24, 65-70. [CrossRef] [PubMed]

49. Peacock, B.N.; Scheiderer, D.J.; Kellermann, G.H. Biomolecular aspects of depression: A retrospective analysis. Compr. Psychiatry 2017, 73, 168-180. [CrossRef] [PubMed]

50. Paine, N.J.; Watkins, L.L.; Blumenthal, J.A.; Kuhn, C.M.; Sherwood, A. Association of Depressive and Anxiety Symptoms with 24-Hour Urinary Catecholamines in Individuals with Untreated High Blood Pressure. Psychosom. Med. 2015, 77, 136-144. [CrossRef] [PubMed]

51. Amelirad, A.; Shamsasenjan, K.; Akbarzadehlaleh, P.; Sarvar, D.P. Signaling Pathways of Receptors Involved in Platelet Activation and Shedding of These Receptors in Stored Platelets. Adv. Pharm. Bull. 2019, 9, 38-47. [CrossRef] 
52. Anfossi, G.; Trovati, M. Role of catecholamines in platelet function: Pathophysiological and clinical significance. Eur. J. Clin. Investig. 1996, 26, 353-370. [CrossRef] [PubMed]

53. Ricci, A.; Bronzetti, E.; Mannino, F.; Mignini, F.; Morosetti, C.; Tayebati, S.K.; Amenta, F. Dopamine receptors in human platelets. Naunyn-Schmiedeberg's Arch. Pharmacol. 2001, 363, 376-382. [CrossRef] [PubMed]

54. Mo, Y.; Li, S.-Y.; Liang, E.-Y.; Lian, Q.-Z.; Meng, F.-Y. The Expression of Functional Dopamine and Serotonin Receptors on Megakaryocytes. Blood 2014, 124, 4205. [CrossRef]

55. Chen, S.; Du, C.; Shen, M.; Zhao, G.; Xu, Y.; Yang, K.; Wang, X.; Li, F.; Zeng, D.; Chen, F.; et al. Sympathetic stimulation facilitates thrombopoiesis by promoting megakaryocyte adhesion, migration, and proplatelet formation. Blood 2016, 127, 1024-1035. [CrossRef] [PubMed]

56. Kjeldsen, S.E.; Weder, A.B.; Egan, B.; Neubig, R.; Zweifler, A.J.; Julius, S. Effect of Circulating Epinephrine on Platelet Function and Hematocrit. Hypertension 1995, 25, 1096-1105. [CrossRef] [PubMed]

57. Tschuor, C.; Asmis, L.M.; Lenzlinger, P.M.; Tanner, M.; Härter, L.; Keel, M.; Stocker, R.; Stover, J.F. In vitro norepinephrine significantly activates isolated platelets from healthy volunteers and critically ill patients following severe traumatic brain injury. Crit. Care 2008, 12, R80. [CrossRef] [PubMed]

58. Schedel, A.; Schloss, P.; Klüter, H.; Bugert, P. The dopamine agonism on ADP-stimulated platelets is mediated through D2-like but not D1-like dopamine receptors. Naunyn-Schmiedeberg's Arch. Pharmacol. 2008, 378, 431-439. [CrossRef] [PubMed]

59. Ardlie, N.G.; McGuiness, J.A.; Garrett, J.J. Effect on human platelets of catecholamines at levels achieved in the circulation. Atherosclerosis 1985, 58, 251-259. [CrossRef]

60. Mills, D.C.B.; Roberts, G.C.K. Effects of adrenaline on human blood platelets. J. Physiol. 1967, 193, $443-453$. [CrossRef]

61. Anfossi, G.; Massucco, P.; Mularoni, E.; Cavalot, F.; Burzacca, S.; Mattiello, L.; Trovati, M. STUDIES ON THE EFFECT OF DOPAMINE ON THE HUMAN PLATELET RESPONSE. Clin. Exp. Pharmacol. Physiol. 1992, 19, 613-618. [CrossRef]

62. Yang, J.; Wu, J.; Jiang, H.; Mortensen, R.; Austin, S.; Manning, D.R.; Woulfe, D.; Brass, L.F. Signaling through Gi family members in platelets. Redundancy and specificity in the regulation of adenylyl cyclase and other effectors. J. Biol. Chem. 2002, 277, 46035-46042. [CrossRef] [PubMed]

63. Woulfe, D.S.; Jiang, H.; Mortensen, R.; Yang, J.; Brass, L.F. Activation of Rap1B by GiFamily Members in Platelets. J. Biol. Chem. 2002, 277, 23382-23390. [CrossRef] [PubMed]

64. Siess, W.; Weber, P.C.; Lapetina, E.G. Activation of phospholipase C is dissociated from arachidonate metabolism during platelet shape change induced by thrombin or platelet-activating factor. Epinephrine does not induce phospholipase C activation or platelet shape change. J. Biol. Chem. 1984, 259, 8286-8292. [PubMed]

65. Laustiola, K.; Kaukinen, S.; Seppälä, E.; Jokela, T.; Vapaatalo, H. Adrenaline infusion evokes increased thromboxane B2production by platelets in healthy men: The effect of beta-adrenoceptor blockade. Eur. J. Clin. Investig. 1986, 16, 473-479. [CrossRef]

66. Wallén, N.H.; Goodall, A.H.; Li, N.; Hjemdahl, P. Activation of haemostasis by exercise, mental stress and adrenaline: Effects on platelet sensitivity to thrombin and thrombin generation. Clin. Sci. 1999, 97, 27-35. [CrossRef]

67. Singh, S.; Malm, C.J.; Ramström, S.; Hesse, C.; Jeppsson, A. Adrenaline enhances in vitro platelet activation and aggregation in blood samples from ticagrelor-treated patients. Res. Pr. Thromb. Haemost. 2018, 2, 718-725. [CrossRef]

68. Singh, S.; Damén, T.; Nygren, A.; Hakimi, C.S.; Ramström, S.; Dellborg, M.; Lindahl, T.L.; Hesse, C.; Jeppsson, A. Adrenaline Improves Platelet Reactivity in Ticagrelor-Treated Healthy Volunteers. Thromb. Haemost. 2019, 119, 735-743. [CrossRef]

69. Lande, K.; Os, L.; Kjeldsen, S.E.; Westheim, A.; Hjermann, L.; Eide, L.; Gjesdal, K. Effect of dopamine and dopamine-antagonist infusion on blood platelet count, size and release reaction in hypertensive and normotensive subjects. Scand. J. Clin. Lab. Investig. 1989, 49, 307-315. [CrossRef]

70. Ha, E.E.; Bauer, R.C. Emerging Roles for Adipose Tissue in Cardiovascular Disease. Arter. Thromb. Vasc. Biol. 2018, 38, e137-e144. [CrossRef]

71. Milaneschi, Y.; Simmons, W.K.; Van Rossum, E.F.C.; Penninx, B.W.J.H. Depression and obesity: Evidence of shared biological mechanisms. Mol. Psychiatry 2018, 24, 18-33. [CrossRef] 
72. Echoe, S.S.; Ehuh, J.Y.; Ehwang, I.J.; Ekim, J.I.; Kim, J.B. Adipose Tissue Remodeling: Its Role in Energy Metabolism and Metabolic Disorders. Front. Endocrinol. 2016, 7, 30. [CrossRef]

73. Lee, T.H.-Y.; Cheng, K.K.-Y.; Hoo, R.L.-C.; Siu, P.M.; Yau, S.Y. The Novel Perspectives of Adipokines on Brain Health. Int. J. Mol. Sci. 2019, 20, 5638. [CrossRef] [PubMed]

74. Lau, W.B.; Ohashi, K.; Wang, Y.; Ogawa, H.; Murohara, T.; Ma, X.-L.; Ouchi, N. Role of Adipokines in Cardiovascular Disease. Circ. J. 2017, 81, 920-928. [CrossRef] [PubMed]

75. Fasshauer, M.; Blüher, M. Adipokines in health and disease. Trends Pharmacol. Sci. 2015, 36, 461-470. [CrossRef] [PubMed]

76. László, A.; Lénárt, L.; Illésy, L.; Fekete, A.; Nemcsik, J. The role of neurotrophins in psychopathology and cardiovascular diseases: Psychosomatic connections. J. Neural Transm. 2019, 126, 265-278. [CrossRef] [PubMed]

77. Zhao, S.; Garvey, W.T. Leptin, An Adipokine with Central Importance in the Global Obesity Problem. Glob. Hear. 2018, 13, 113-127. [CrossRef]

78. Crujeiras, A.B.; Carreira, M.C.; Cabia, B.; Andrade, S.; Amil, M.; Casanueva, F.F. Leptin resistance in obesity: An epigenetic landscape. Life Sci. 2015, 140, 57-63. [CrossRef]

79. Liberale, L.; Bonaventura, A.; Vecchié, A.; Matteo, C.; Dallegri, F.; Montecucco, F.; Carbone, F.; Casula, M. The Role of Adipocytokines in Coronary Atherosclerosis. Curr. Atheroscler. Rep. 2017, 19, 10. [CrossRef]

80. Rao, V.S.; Ravindran, V.; Dhanalakshmi, B.; Hebbagodi, S.; Kakkar, V.V.; Shanker, J. Relationship of adiponectin and leptin to coronary artery disease, classical cardiovascular risk factors and atherothrombotic biomarkers in the IARS cohort. Thromb. Haemost. 2012, 108, 769-780. [CrossRef]

81. Taneli, F.; Yegane, S.; Ulman, C.; Tikiz, H.; Bilge, A.R.; Ari, Z.; Uyanik, B.S.; Ulman, I. Increased Serum Leptin Concentrations in Patients with Chronic Stable Angina Pectoris and ST-Elevated Myocardial Infarction. Angiology 2006, 57, 267-272. [CrossRef]

82. Khafaji, H.A.R.; Bener, A.; Rizk, N.M.; Al Suwaidi, J. Elevated serum leptin levels in patients with acute myocardial infarction; correlation with coronary angiographic and echocardiographic findings. BMC Res. Notes 2012, 5, 262. [CrossRef] [PubMed]

83. Puurunen, V.-P.; Kiviniemi, A.; Lepojärvi, E.S.; Piira, O.-P.; Hedberg, P.; Junttila, J.; Ukkola, O.; Huikuri, H. Leptin predicts short-term major adverse cardiac events in patients with coronary artery disease. Ann. Med. 2017, 49, 448-454. [CrossRef] [PubMed]

84. Bickel, C.; Schnabel, R.B.; Zeller, T.; Lackner, K.J.; Rupprecht, H.J.; Blankenberg, S.; Sinning, C.; Westermann, D. Predictors of leptin concentration and association with cardiovascular risk in patients with coronary artery disease: Results from the AtheroGene study. Biomarkers 2016, 22, 210-218. [CrossRef] [PubMed]

85. Van Doorn, C.; Macht, V.A.; Grillo, C.A.; Reagan, L.P. Leptin resistance and hippocampal behavioral deficits. Physiol. Behav. 2017, 176, 207-213. [CrossRef]

86. Wędrychowicz, A.Z.A.; Zając, A.; Pilecki, M.; Kościelniak, B.; Tomasik, P.J. Peptides from adipose tissue in mental disorders. World J. Psychiatry 2014, 4, 103-111. [CrossRef]

87. Jow, G.-M.; Yang, T.-T.; Chen, C.-L. Leptin and cholesterol levels are low in major depressive disorder, but high in schizophrenia. J. Affect. Disord. 2006, 90, 21-27. [CrossRef]

88. Yang, K.; Xie, G.; Zhang, Z.; Wang, C.; Li, W.; Zhou, W.; Tang, Y. Levels of serum interleukin (IL)-6, IL-1beta, tumour necrosis factor-alpha and leptin and their correlation in depression. Aust. N. Z. J. Psychiatry 2007, 41, 266-273. [CrossRef]

89. Eikelis, N.; Esler, M.; Barton, D.; Dawood, T.; Wiesner, G.; Lambert, G. Reduced brain leptin in patients with major depressive disorder and in suicide victims. Mol. Psychiatry 2006, 11, 800-801. [CrossRef]

90. Kraus, T.; Haack, M.; Schuld, A.; Hinze-Selch, D.; Pollmächer, T. Low leptin levels but normal body mass indices in patients with depression or schizophrenia. Neuroendocrinology 2001, 73, 243-247. [CrossRef]

91. Lu, X.-Y.; Kim, C.S.; Frazer, A.; Zhang, W. Leptin: A potential novel antidepressant. Proc. Natl. Acad. Sci. USA 2006, 103, 1593-1598. [CrossRef]

92. Cordeiro, R.C.; Filho, A.J.M.C.; Gomes, N.S.; Tomaz, V.D.S.; Medeiros, C.D.; Queiroz, A.I.D.G.; Maes, M.; Macedo, D.; Carvalho, A.F. Leptin Prevents Lipopolysaccharide-Induced Depressive-Like Behaviors in Mice: Involvement of Dopamine Receptors. Front. Psychiatry 2019, 10, 125. [CrossRef] [PubMed]

93. Zou, X.; Zhong, L.; Zhu, C.; Zhao, H.; Zhao, F.; Cui, R.; Gao, S.; Li, B. Role of Leptin in Mood Disorder and Neurodegenerative Disease. Front. Neurosci. 2019, 13, 378. [CrossRef] [PubMed] 
94. Aschbacher, K.; Rodriguez-Fernandez, M.; Van Wietmarschen, H.; Tomiyama, A.J.; Jain, S.; Epel, E.S.; Doyle, F.J.; Van Der Greef, J. The hypothalamic-pituitary-adrenal-leptin axis and metabolic health: A systems approach to resilience, robustness and control. Interface Focus 2014, 4, 20140020. [CrossRef] [PubMed]

95. Iwasa, T.; Matsuzaki, T.; Yano, K.; Munkhzaya, M.; Tungalagsuvd, A.; Yiliyasi, M.; Kuwahara, A.; Irahara, M. Developmental changes in the hypothalamic mRNA expression levels of brain-derived neurotrophic factor and serum leptin levels: Their responses to fasting in male and female rats. Int. J. Dev. Neurosci. 2016, 54, 1-5. [CrossRef]

96. Liao, G.-Y.; An, J.J.; Gharami, K.; Waterhouse, E.G.; Vanevski, F.; Jones, K.R.; Xu, B. Dendritically targeted Bdnf mRNA is essential for energy balance and response to leptin. Nat. Med. 2012, 18, 564-571. [CrossRef] [PubMed]

97. Stranahan, A.M.; Arumugam, T.V.; Mattson, M.P. Lowering corticosterone levels reinstates hippocampal brain-derived neurotropic factor and Trkb expression without influencing deficits in hypothalamic brain-derived neurotropic factor expression in leptin receptor-deficient mice. Neuroendocrinology 2010, 93, 58-64. [CrossRef] [PubMed]

98. Guo, M.; Huang, T.-Y.; Garza, J.C.; Chua, S.C.; Lu, X.-Y. Selective deletion of leptin receptors in adult hippocampus induces depression-related behaviours. Int. J. Neuropsychopharmacol. 2013, 16, 857-867. [CrossRef]

99. Ieraci, A.; Barbieri, S.S.; Macchi, C.; Amadio, P.; Sandrini, L.; Magni, P.; Popoli, M.; Ruscica, M. BDNF Val66Met polymorphism alters food intake and hypothalamic BDNF expression in mice. J. Cell. Physiol. 2020, 235, 9667-9675. [CrossRef]

100. Kauffman, R.P.; Castracane, V.D.; White, D.L.; Baldock, S.D.; Owens, R. Impact of the selective serotonin reuptake inhibitor citalopram on insulin sensitivity, leptin and basal cortisol secretion in depressed and non-depressed euglycemic women of reproductive age. Gynecol. Endocrinol. 2005, 21, 129-137. [CrossRef]

101. Kotan, Z.; Sarandol, E.; Kırhan, E.; Özkaya, G.; Kırl1, S. Serum brain-derived neurotrophic factor, vascular endothelial growth factor and leptin levels in patients with a diagnosis of severe major depressive disorder with melancholic features. Ther. Adv. Psychopharmacol. 2012, 2, 65-74. [CrossRef]

102. Strauss, M.; Mergl, R.; Kratzsch, J.; Brügel, M.; Strauss, E.; Hegerl, U.; Schoenknecht, P. Differentiation between free and bound leptin in depressed patients. Psychiatry Res. 2014, 219, 397-399. [CrossRef]

103. Tunçel, Ö.K.; Akbaş, S.; Bilgici, B. Increased Ghrelin Levels and Unchanged Adipocytokine Levels in Major Depressive Disorder. J. Child Adolesc. Psychopharmacol. 2016, 26, 733-739. [CrossRef]

104. Esel, E.; Ozsoy, S.; Tutus, A.; Sofuoglu, S.; Kartalci, S.; Bayram, F.; Kokbudak, Z.; Kula, M. Effects of antidepressant treatment and of gender on serum leptin levels in patients with major depression. Prog. Neuro-Psychopharmacol. Biol. Psychiatry 2005, 29, 565-570. [CrossRef]

105. Shelton, R.C.; Falola, M.; Li, L.; Zajecka, J.; Fava, M.; Papakostas, G.I. The pro-inflammatory profile of depressed patients is (partly) related to obesity. J. Psychiatr. Res. 2015, 70, 91-97. [CrossRef]

106. Milaneschi, Y.; Lamers, F.; Bot, M.; Drent, M.L.; Penninx, B.W.J.H. Leptin Dysregulation Is Specifically Associated with Major Depression with Atypical Features: Evidence for a Mechanism Connecting Obesity and Depression. Biol. Psychiatry 2017, 81, 807-814. [CrossRef]

107. Lasserre, A.M.; Strippoli, M.-P.F.; Glaus, J.; Gholam-Rezaee, M.; Vandeleur, C.L.; Castelao, E.; Marques-Vidal, P.; Waeber, G.; Vollenweider, P.; Preisig, M. Prospective associations of depression subtypes with cardio-metabolic risk factors in the general population. Mol. Psychiatry 2016, 22, 1026-1034. [CrossRef]

108. Çakici, N.; Bot, M.; Lamers, F.; Janssen, T.; Van Der Spek, P.J.; De Haan, L.; Bahn, S.; Penninx, B.W.; Van Beveren, N.J. Increased serum levels of leptin and insulin in both schizophrenia and major depressive disorder: A cross-disorder proteomics analysis. Eur. Neuropsychopharmacol. 2019, 29, 835-846. [CrossRef]

109. Syk, M.; Ellström, S.; Mwinyi, J.; Schiöth, H.B.; Ekselius, L.; Ramklint, M.; Cunningham, J.L. Plasma levels of leptin and adiponectin and depressive symptoms in young adults. Psychiatry Res. 2019, 272, 1-7. [CrossRef]

110. Takekawa, D.; Kudo, T.; Saito, J.; Kimura, F.; Nikaido, Y.; Sawada, K.; Yasui-Furukori, N.; Hirota, K. Higher plasma leptin and lower C-peptide levels are associated with depression: A cross-sectional study. J. Affect. Disord. 2019, 243, 70-74. [CrossRef]

111. Carvalho, A.F.; Rocha, D.Q.; McIntyre, R.S.; Mesquita, L.M.; Köhler, C.A.; Hyphantis, T.; Sales, P.M.; Machado-Vieira, R.; Berk, M. Adipokines as emerging depression biomarkers: A systematic review and meta-analysis. J. Psychiatr. Res. 2014, 59, 28-37. [CrossRef] 
112. Licinio, J.; Negrão, A.B.; Mantzoros, C.; Kaklamani, V.; Wong, M.L.; Bongiorno, P.B.; Negro, P.P.; Mulla, A.; Veldhuis, J.D.; Cearnal, L.; et al. Sex differences in circulating human leptin pulse amplitude: Clinical implications. J. Clin. Endocrinol. Metab. 1998, 83, 4140-4147. [CrossRef]

113. Mills, J.G.; Thomas, S.J.; Larkin, T.A.; Pai, N.; Deng, C. Problematic eating behaviours, changes in appetite, and weight gain in Major Depressive Disorder: The role of leptin. J. Affect. Disord. 2018, 240, 137-145. [CrossRef]

114. Endomba, F.T.; Tankeu, A.T.; Nkeck, J.R.; Tochie, J.N. Leptin and psychiatric illnesses: Does leptin play a role in antipsychotic-induced weight gain? Lipids Health Dis. 2020, 19, 1-12. [CrossRef]

115. Gecici, O.; Kuloglu, M.; Atmaca, M.; Tezcan, A.E.; Tunckol, H.; Emül, H.M.; Ustündağ, B. High serum leptin levels in depressive disorders with atypical features. Psychiatry Clin. Neurosci. 2005, 59, 736-738. [CrossRef]

116. Giandomenico, G.; Dellas, C.; Czekay, R.-P.; Koschnick, S.; Loskutoff, D.J. The leptin receptor system of human platelets. J. Thromb. Haemost. 2005, 3, 1042-1049. [CrossRef]

117. Konstantinides, S.; Schäfer, K.; Koschnick, S.; Loskutoff, D.J. Leptin-dependent platelet aggregation and arterial thrombosis suggests a mechanism for atherothrombotic disease in obesity. J. Clin. Investig. 2001, 108, 1533-1540. [CrossRef]

118. Konstantinides, S.; Schafer, K.; Loskutoff, D.J. The prothrombotic effects of leptin possible implications for the risk of cardiovascular disease in obesity. Ann. N. Y. Acad. Sci. 2001, 947, 134-141. [CrossRef]

119. Elbatarny, H.S.; Maurice, D.H. Leptin-mediated activation of human platelets: Involvement of a leptin receptor and phosphodiesterase 3A-containing cellular signaling complex. Am. J. Physiol. Metab. 2005, 289, E695-E702. [CrossRef]

120. Elbatarny, H.S.; Netherton, S.J.; Ovens, J.D.; Ferguson, A.V.; Maurice, D.H. Adiponectin, ghrelin, and leptin differentially influence human platelet and human vascular endothelial cell functions: Implication in obesity-associated cardiovascular diseases. Eur. J. Pharmacol. 2007, 558, 7-13. [CrossRef]

121. Nakata, M.; Yada, T.; Soejima, N.; Maruyama, I. Leptin promotes aggregation of human platelets via the long form of its receptor. Diabetes 1999, 48, 426-429. [CrossRef]

122. Corsonello, A.; Perticone, F.; Malara, A.; De Domenico, D.; Loddo, S.; Buemi, M.; Ientile, R.; Corica, F. Leptin-dependent platelet aggregation in healthy, overweight and obese subjects. Int. J. Obes. 2003, 27, 566-573. [CrossRef] [PubMed]

123. Ozata, M.; Avcu, F.; Durmus, O.; Yilmaz, I.; Ozdemir, I.C.; Yalcin, A. Leptin Does Not Play a Major Role in Platelet Aggregation in Obesity and Leptin Deficiency. Obes. Res. 2001, 9, 627-630. [CrossRef] [PubMed]

124. Vilahur, G.; Ben-Aicha, S.; Badimon, L. New insights into the role of adipose tissue in thrombosis. Cardiovasc. Res. 2017, 113, 1046-1054. [CrossRef] [PubMed]

125. Pischon, T.; Girman, C.; Hotamisligil, G.; Rifai, N.; Hu, F.; Rimm, E. Plasma adiponectin levels and risk of myocardial infarction in men. ACC Curr. J. Rev. 2004, 13, 20. [CrossRef]

126. Maahs, D.M.; Ogden, L.G.; Kinney, G.L.; Wadwa, P.; Snell-Bergeon, J.K.; Dabelea, D.; Hokanson, J.E.; Ehrlich, J.; Eckel, R.H.; Rewers, M.; et al. Low Plasma Adiponectin Levels Predict Progression of Coronary Artery Calcification. Circulation 2005, 111, 747-753. [CrossRef]

127. Wolk, R.; Berger, P.; Lennon, R.J.; Brilakis, E.S.; Davison, D.E.; Somers, V.K. Association between plasma adiponectin levels and unstable coronary syndromes. Eur. Hear. J. 2007, 28, 292-298. [CrossRef]

128. Adya, R.; Tan, B.K.; Randeva, H.S. Differential Effects of Leptin and Adiponectin in Endothelial Angiogenesis. J. Diabetes Res. 2015, 2015, 1-12. [CrossRef]

129. Golia, E.; Limongelli, G.; Natale, F.; Fimiani, F.; Maddaloni, V.; Russo, P.E.; Riegler, L.; Bianchi, R.; Crisci, M.; Di Palma, G.; et al. Adipose tissue and vascular inflammation in coronary artery disease. World J. Cardiol. 2014, 6, 539-554. [CrossRef]

130. Diniz, B.S.; Teixeira, A.L.; Campos, A.C.; Miranda, A.S.; Rocha, N.P.; Talib, L.L.; Gattaz, W.F.; Forlenza, O.V. Reduced serum levels of adiponectin in elderly patients with major depression. J. Psychiatr. Res. 2012, 46, 1081-1085. [CrossRef]

131. Lehto, S.M.; Huotari, A.; Niskanen, L.; Tolmunen, T.; Koivumaa-Honkanen, H.; Honkalampi, K.; Ruotsalainen, H.; Herzig, K.-H.; Viinamäki, H.; Hintikka, J. Serum adiponectin and resistin levels in major depressive disorder. Acta Psychiatr. Scand. 2010, 121, 209-215. [CrossRef]

132. Leo, R.; Di Lorenzo, G.; Tesauro, M.; Cola, C.; Fortuna, E.; Zanasi, M.; Troisi, A.; Siracusano, A.; Lauro, R.; Romeo, F. Decreased plasma adiponectin concentration in major depression. Neurosci. Lett. 2006, 407, 211-213. [CrossRef] [PubMed] 
133. Su, S.-C.; Sun, M.-T.; Wen, M.-J.; Lin, C.-J.; Chen, Y.-C.; Hung, Y.-J. Brain-derived neurotrophic factor, adiponectin, and proinflammatory markers in various subtypes of depression in young men. Int. J. Psychiatry Med. 2011, 42, 211-226. [CrossRef] [PubMed]

134. Cao, B.; Chen, Y.; Brietzke, E.; Cha, D.; Shaukat, A.; Pan, Z.; Park, C.; Subramaniapillai, M.; Zuckerman, H.; Grant, K.; et al. Leptin and adiponectin levels in major depressive disorder: A systematic review and meta-analysis. J. Affect. Disord. 2018, 238, 101-110. [CrossRef] [PubMed]

135. Narita, K.; Murata, T.; Takahashi, T.; Kosaka, H.; Omata, N.; Wada, Y. Plasma levels of adiponectin and tumor necrosis factor-alpha in patients with remitted major depression receiving long-term maintenance antidepressant therapy. Prog. Neuro-Psychopharmacol. Biol. Psychiatry 2006, 30, 1159-1162. [CrossRef] [PubMed]

136. Zeman, M.; Jirák, R.; Jachymova, M.; Vecka, M.; Tvrzicka, E.; Žák, A. Leptin, adiponectin, leptin to adiponectin ratio and insulin resistance in depressive women. Neuro Endocrinol. Lett. 2009, 30, 387-395.

137. Cizza, G.; Nguyen, V.T.; Eskandari, F.; Duan, Z.; Wright, E.C.; Reynolds, J.C.; Ahima, R.S.; Blackman, M.R. POWER Study Group Low 24-hour adiponectin and high nocturnal leptin concentrations in a case-control study of community-dwelling premenopausal women with major depressive disorder: The Premenopausal, Osteopenia/Osteoporosis, Women, Alendronate, Depression (POWER) study. J. Clin. Psychiatry 2010, 71, 1079-1087. [CrossRef]

138. Jeong, H.-G.; Min, B.J.; Lim, S.; Kim, T.H.; Lee, J.J.; Park, J.H.; Lee, S.B.; Han, J.W.; Choi, S.H.; Park, Y.J.; et al. Plasma adiponectin elevation in elderly individuals with subsyndromal depression. Psychoneuroendocrinology 2012, 37, 948-955. [CrossRef]

139. Einvik, G.; Flyvbjerg, A.; Hrubos-Strøm, H.; Randby, A.; Frystyk, J.; Bjerre, M.; Namtvedt, S.K.; Kristiansen, H.A.; Nordhus, I.H.; Somers, V.K.; et al. Novel cardiovascular risk markers in depression: No association between depressive symptoms and osteoprotegerin or adiponectin in persons at high risk for sleep apnea. J. Affect. Disord. 2013, 145, 400-404. [CrossRef]

140. Bai, Y.-M.; Chiou, W.-F.; Su, T.-P.; Li, C.-T.; Chen, M.-H. Pro-inflammatory cytokine associated with somatic and pain symptoms in depression. J. Affect. Disord. 2014, 155, 28-34. [CrossRef]

141. Pan, A.; Ye, X.; Franco, O.H.; Li, H.; Yu, Z.; Wang, J.; Qi, Q.; Gu, W.; Pang, X.; Liu, H.; et al. The Association of Depressive Symptoms with Inflammatory Factors and Adipokines in Middle-Aged and Older Chinese. PLoS ONE 2008, 3, e1392. [CrossRef]

142. Wulan, S.; Westerterp, K.; Plasqui, G. Ethnic differences in body composition and the associated metabolic profile: A comparative study between Asians and Caucasians. Maturitas 2010, 65, 315-319. [CrossRef] [PubMed]

143. Cnop, M.; Havel, P.J.; Utzschneider, K.M.; Carr, D.B.; Sinha, M.K.; Boyko, E.J.; Retzlaff, B.M.; Knopp, R.H.; Brunzell, J.D.; Kahn, S.E. Relationship of adiponectin to body fat distribution, insulin sensitivity and plasma lipoproteins: Evidence for independent roles of age and sex. Diabetologia 2003, 46, 459-469. [CrossRef] [PubMed]

144. Zeugmann, S.; Quante, A.; Heuser, I.; Schwarzer, R.; Anghelescu, I. Inflammatory Biomarkers in 70 Depressed Inpatients with and Without the Metabolic Syndrome. J. Clin. Psychiatry 2010, 71, 1007-1016. [CrossRef] [PubMed]

145. Hung, Y.-J.; Hsieh, C.-H.; Chen, Y.-J.; Pei, D.; Kuo, S.-W.; Shen, D.-C.; Sheu, W.H.-H.; Chen, Y.-C. Insulin sensitivity, proinflammatory markers and adiponectin in young males with different subtypes of depressive disorder. Clin. Endocrinol. 2007, 67, 784-789. [CrossRef]

146. Platzer, M.; Fellendorf, F.T.; Bengesser, S.A.; Birner, A.; Dalkner, N.; Hamm, C.; Hartleb, R.; Queissner, R.; Pilz, R.; Rieger, A.; et al. Adiponectin is decreased in bipolar depression. World J. Biol. Psychiatry 2018, 20, 813-820. [CrossRef]

147. Lamers, F.; Bot, M.; Jansen, R.; Chan, M.K.; Cooper, J.D.; Bahn, S.; Penninx, B.W.J.H. Serum proteomic profiles of depressive subtypes. Transl. Psychiatry 2016, 6, e851. [CrossRef]

148. Kato, H.; Kashiwagi, H.; Shiraga, M.; Tadokoro, S.; Kamae, T.; Ujiie, H.; Honda, S.; Miyata, S.; Ijiri, Y.; Yamamoto, J.; et al. Adiponectin Acts as an Endogenous Antithrombotic Factor. Arter. Thromb. Vasc. Biol. 2006, 26, 224-230. [CrossRef]

149. Shoji, T.; Koyama, H.; Fukumoto, S.; Maeno, T.; Yokoyama, H.; Shinohara, K.; Emoto, M.; Shoji, T.; Yamane, T.; Hino, M.; et al. Platelet activation is associated with hypoadiponectinemia and carotid atherosclerosis. Atherosclerosis 2006, 188, 190-195. [CrossRef] 
150. Okamoto, Y.; Ishii, S.; Croce, K.; Katsumata, H.; Fukushima, M.; Kihara, S.; Libby, P.; Minami, S. Adiponectin inhibits macrophage tissue factor, a key trigger of thrombosis in disrupted atherosclerotic plaques. Atherosclerosis 2013, 226, 373-377. [CrossRef]

151. Chao, M.V.; Rajagopal, R.; Lee, F.S. Neurotrophin signalling in health and disease. Clin. Sci. 2006, 110, 167-173. [CrossRef]

152. Tabakman, R.; Lecht, S.; Sephanova, S.; Arien-Zakay, H.; Lazarovici, P. Interactions between the cells of the immune and nervous system: Neurotrophins as neuroprotection mediators in CNS injury. Prog. Brain Res. 2004, 146, 387-401. [CrossRef] [PubMed]

153. Fiore, M.; Chaldakov, G.N.; Aloe, L. Nerve Growth Factor as a Signaling Molecule for Nerve Cells and also for the Neuroendocrine-Immune Systems. Rev. Neurosci. 2009, 20, 133-145. [CrossRef]

154. Amadio, P.; Baldassarre, D.; Sandrini, L.; Weksler, B.B.; Tremoli, E.; Barbieri, S.S. Effect of cigarette smoke on monocyte procoagulant activity: Focus on platelet-derived brain-derived neurotrophic factor (BDNF). Platelets 2016, 28, 60-65. [CrossRef] [PubMed]

155. Lazarovici, P.; Marcinkiewicz, C.; Lelkes, P. Cross Talk between the Cardiovascular and Nervous Systems: Neurotrophic Effects of Vascular Endothelial Growth Factor (VEGF) and Angiogenic Effects of Nerve Growth Factor (NGF)-Implications in Drug Development. Curr. Pharm. Des. 2006, 12, 2609-2622. [CrossRef] [PubMed]

156. Raab, S.; Plate, K.H. Different networks, common growth factors: Shared growth factors and receptors of the vascular and the nervous system. Acta Neuropathol. 2007, 113, 607-626. [CrossRef]

157. Aloe, L.; Tirassa, P.; Lambiase, A. The topical application of nerve growth factor as a pharmacological tool for human corneal and skin ulcers. Pharmacol. Res. 2008, 57, 253-258. [CrossRef]

158. Chaldakov, G.N.; Tonchev, A.B.; Aloe, L. NGF and BDNF: From nerves to adipose tissue, from neurokines to metabokines. Riv. Psichiatr. 2010, 44, 79-87.

159. Gomez-Pinilla, F.; Vaynman, S.; Ying, Z. Brain-derived neurotrophic factor functions as a metabotrophin to mediate the effects of exercise on cognition. Eur. J. Neurosci. 2008, 28, 2278-2287. [CrossRef]

160. Apparao, A. Views and opinion on BDNF as a target for diabetic cognitive dysfunction. Bioinformation 2013, 9,551-554. [CrossRef]

161. Meek, T.H.; Wisse, B.E.; Thaler, J.P.; Guyenet, S.J.; Matsen, M.E.; Fischer, J.D.; Taborsky, G.J.; Schwartz, M.W.; Morton, G.J. BDNF Action in the Brain Attenuates Diabetic Hyperglycemia via Insulin-Independent Inhibition of Hepatic Glucose Production. Diabetes 2013, 62, 1512-1518. [CrossRef]

162. Yanev, S.; Yanev, L.A.S. Neurotrophic and metabotrophic potential of nerve growth factor and brain-derived neurotrophic factor: Linking cardiometabolic and neuropsychiatric diseases. World J. Pharmacol. 2013, 2, 92. [CrossRef]

163. Alhusban, A.; Kozak, A.; Pillai, B.; Ahmed, H.; Sayed, M.A.; Johnson, M.H.; Ishrat, T.; Ergul, A.; Fagan, S.C. Mechanisms of acute neurovascular protection with AT1 blockade after stroke: Effect of prestroke hypertension. PLoS ONE 2017, 12, e0178867. [CrossRef]

164. Amadio, P.; Porro, B.; Sandrini, L.; Fiorelli, S.; Bonomi, A.; Cavalca, V.; Brambilla, M.; Camera, M.; Veglia, F.; Tremoli, E.; et al. Patho- physiological role of BDNF in fibrin clotting. Sci. Rep. 2019, 9, 389. [CrossRef]

165. Emanueli, C.; Meloni, M.; Hasan, W.; Habecker, B.A. The Biology of Neurotrophins: Cardiovascular Function. In Neurotrophic Factors. Handbook of Experimental Pharmacology; Lewin, G., Carter, B., Eds.; Springer: Heidelberg/Berlin, Germany, 2014; Volume 220, pp. 309-328.

166. Pius-Sadowska, E.; Machaliński, B. BDNF-A key player in cardiovascular system. J. Mol. Cell. Cardiol. 2017, 110, 54-60. [CrossRef]

167. Becker, B.; Wang, H.; Tian, C.; Zucker, I.H. BDNF contributes to angiotensin II-mediated reductions in peak voltage-gated K+current in cultured CATH.a cells. Physiol. Rep. 2015, 3, e12598. [CrossRef] [PubMed]

168. Becker, B.; Wang, H.; Zucker, I.H. Central TrkB blockade attenuates ICV angiotensin II-hypertension and sympathetic nerve activity in male Sprague-Dawley rats. Auton. Neurosci. 2017, 205, 77-86. [CrossRef] [PubMed]

169. Lee, I.-T.; Lee, W.-J.; Tsai, I.-C.; Liang, K.-W.; Lin, S.-Y.; Wan, C.-J.; Fu, C.-P.; Sheu, W.H.-H. Brain-derived neurotrophic factor not associated with metabolic syndrome but inversely correlated with vascular cell adhesion molecule-1 in men without diabetes. Clin. Chim. Acta 2012, 413, 944-948. [CrossRef] [PubMed] 
170. Chaldakov, G.N.; Fiore, M.; Stankulov, I.S.; Manni, L.; Hristova, M.G.; Antonelli, A.; Ghenev, P.I.; Aloe, L. Neurotrophin presence in human coronary atherosclerosis and metabolic syndrome: A role for NGF and BDNF in cardiovascular disease? Prog. Brain Res. 2004, 146, 279-289. [CrossRef] [PubMed]

171. Lorgis, L.; Amoureux, S.; De Maistre, E.; Sicard, P.; Béjot, Y.; Zeller, M.; Vergely, C.; Grand, A.S.-L.; Lagrost, A.-C.; Berchoud, J.; et al. Serum brain-derived neurotrophic factor and platelet activation evaluated by soluble P-selectin and soluble CD-40-ligand in patients with acute myocardial infarction. Fundam. Clin. Pharmacol. 2009, 24, 525-530. [CrossRef]

172. Manni, L.; Nikolova, V.; Vyagova, D.; Chaldakov, G.N.; Aloe, L. Reduced plasma levels of NGF and BDNF in patients with acute coronary syndromes. Int. J. Cardiol. 2005, 102, 169-171. [CrossRef]

173. Krabbe, K.S.; Nielsen, A.R.; Krogh-Madsen, R.; Plomgaard, P.; Rasmussen, P.; Erikstrup, C.; Fischer, C.P.; Lindegaard, B.; Petersen, A.M.W.; Taudorf, S.; et al. Brain-derived neurotrophic factor (BDNF) and type 2 diabetes. Diabetologia 2007, 50, 2029-2030. [CrossRef]

174. Donovan, M.J.; Hahn, R.; Tessarollo, L.; Hempstead, B.L. Identification of an essential nonneuronal function of neurotrophin 3 in mammalian cardiac development. Nat. Genet. 1996, 14, 210-213. [CrossRef]

175. Lam, N.T.; Currie, P.D.; Lieschke, G.J.; Rosenthal, N.A.; Kaye, D.M. Nerve Growth Factor Stimulates Cardiac Regeneration via Cardiomyocyte Proliferation in Experimental Heart Failure. PLoS ONE 2012, 7, e53210. [CrossRef]

176. Cristofaro, B.; Stone, O.A.; Caporali, A.; Dawbarn, D.; Ieronimakis, N.; Reyes, M.; Madeddu, P.; Bates, D.O.; Emanueli, C. Neurotrophin-3 Is a Novel Angiogenic Factor Capable of Therapeutic Neovascularization in a Mouse Model of Limb Ischemia. Arter. Thromb. Vasc. Biol. 2010, 30, 1143-1150. [CrossRef] [PubMed]

177. Zhang, S.-H.; Rush, R.A. Neurotrophin 3 is increased in the spontaneously hypertensive rat. J. Hypertens. 2001, 19, 2251-2256. [CrossRef] [PubMed]

178. Yao, Q.; Song, R.; Ao, L.; Cleveland, J.C.; Fullerton, D.A.; Meng, X. Neurotrophin 3 upregulates proliferation and collagen production in human aortic valve interstitial cells: A potential role in aortic valve sclerosis. Am. J. Physiol. Physiol. 2017, 312, C697-C706. [CrossRef] [PubMed]

179. Amadio, P.; Colombo, G.; Tarantino, E.; Gianellini, S.; Ieraci, A.; Brioschi, M.; Banfi, C.; Werba, J.P.; Parolari, A.; Lee, F.S.; et al. BDNFVal66met polymorphism: A potential bridge between depression and thrombosis. Eur. Hear. J. 2015, 38, ehv655. [CrossRef] [PubMed]

180. Kim, J.-M.; Stewart, R.; Kim, S.-Y.; Kim, J.-W.; Kang, H.-J.; Lee, J.-Y.; Kim, S.-W.; Shin, I.-S.; Kim, M.C.; Hong, Y.J.; et al. Interaction between BDNF val66met polymorphism and personality on long-term cardiac outcomes in patients with acute coronary syndrome. PLoS ONE 2019, 14, e0226802. [CrossRef]

181. Liu, Y.-Q.; Su, G.-B.; Duan, C.-H.; Wang, J.-H.; Liu, H.-M.; Feng, N.; Wang, Q.-X.; Liu, X.-E.; Zhang, J. Brain-derived neurotrophic factor gene polymorphisms are associated with coronary artery disease-related depression and antidepressant response. Mol. Med. Rep. 2014, 10, 3247-3253. [CrossRef]

182. Sandrini, L.; Castiglioni, L.; Amadio, P.; Werba, J.P.; Eligini, S.; Fiorelli, S.; Zarà, M.; Castiglioni, S.; Bellosta, S.; Lee, F.S.; et al. Impact of BDNF Val66Met Polymorphism on Myocardial Infarction: Exploring the Macrophage Phenotype. Cells 2020, 9, 1084. [CrossRef]

183. Berezin, A.; Petyunina, O.; Kopytsya, M.; Skrynnyk, O. The role of Val66Met single nucleotide polymorphism in brain-derived neurotropic factor gene in prediction of adverse outcomes after ST-segment elevation myocardial infarction. Hear. Mind 2019, 3, 7. [CrossRef]

184. Amirlatifi, R.; Farazmandfar, T.; Sharifian, S.A.; Manzari, R.S.; Shahbazi, M. Association assessment of Nerve growth factor gene promoter polymorphism and its expression status with susceptibility to coronary artery disease. Meta Gene 2018, 15, 31-34. [CrossRef]

185. Sofer, T.; Wong, Q.; Hartwig, F.P.; Taylor, K.; Warren, H.R.; Evangelou, E.; Cabrera, C.P.; Levy, D.; Kramer, H.; Lange, L.A.; et al. Genome-Wide Association Study of Blood Pressure Traits by Hispanic/Latino Background: The Hispanic Community Health Study/Study of Latinos. Sci. Rep. 2017, 7, 10348. [CrossRef] [PubMed]

186. Lin, C.-C.; Huang, T.-L. Brain-derived neurotrophic factor and mental disorders. Biomed. J. 2020, 43, $134-142$. [CrossRef]

187. Schmidt, H.D.; Duman, R.S. Peripheral BDNF Produces Antidepressant-Like Effects in Cellular and Behavioral Models. Neuropsychopharmacology 2010, 35, 2378-2391. [CrossRef]

188. Shi, C.-G.; Wang, L.-M.; Wu, Y.; Wang, P.; Gan, Z.-J.; Lin, K.; Jiang, L.-X.; Xu, Z.-Q.D.; Efan, M. Intranasal Administration of Nerve Growth Factor Produces Antidepressant-Like Effects in Animals. Neurochem. Res. 2010, 35, 1302-1314. [CrossRef] 
189. Barbosa, I.G.; Morato, I.B.; Huguet, R.B.; Rocha, F.L.; Machado-Vieira, R.; Teixeira, A.L. Decreased plasma neurotrophin-4/5 levels in bipolar disorder patients in mania. Braz. J. Psychiatry 2014, 36, 340-343. [CrossRef]

190. Lin, C.-Y.; Hung, S.-Y.; Chen, H.-T.; Tsou, H.-K.; Fong, Y.-C.; Wang, S.-W.; Tang, C.-H. Brain-derived neurotrophic factor increases vascular endothelial growth factor expression and enhances angiogenesis in human chondrosarcoma cells. Biochem. Pharmacol. 2014, 91, 522-533. [CrossRef]

191. Lee, B.-H.; Kim, Y.-K. The Roles of BDNF in the Pathophysiology of Major Depression and in Antidepressant Treatment. Psychiatry Investig. 2010, 7, 231-235. [CrossRef]

192. Tramontina, J.F.; Yates, D.; Magalhaes, P.V.S.; Trentini, C.; Sant'Anna, M.K.; Fries, G.R.; Bock, H.; Saraiva-Pereira, M.L.; Kapczinski, F. Brain-derived neurotrophic factor gene val66met polymorphism and executive functioning in patients with bipolar disorder. Rev. Bras. de Psiquiatr. 2009, 31, 136-140. [CrossRef]

193. Maina, G.; Rosso, G.; Zanardini, R.; Bogetto, F.; Gennarelli, M.; Bocchio-Chiavetto, L. Serum levels of brain-derived neurotrophic factor in drug-naïve obsessive-compulsive patients: A case-control study. J. Affect. Disord. 2010, 122, 174-178. [CrossRef] [PubMed]

194. Lee, B.-H.; Kim, H.; Park, S.-H.; Kim, Y.-K. Decreased plasma BDNF level in depressive patients. J. Affect. Disord. 2007, 101, 239-244. [CrossRef] [PubMed]

195. Yoshida, T.; Ishikawa, M.; Niitsu, T.; Nakazato, M.; Watanabe, H.; Shiraishi, T.; Shiina, A.; Hashimoto, T.; Kanahara, N.; Hasegawa, T.; et al. Decreased Serum Levels of Mature Brain-Derived Neurotrophic Factor (BDNF), but Not Its Precursor proBDNF, in Patients with Major Depressive Disorder. PLoS ONE 2012, 7, e42676. [CrossRef] [PubMed]

196. Shimizu, E.; Hashimoto, K.; Okamura, N.; Koike, K.; Komatsu, N.; Kumakiri, C.; Nakazato, M.; Watanabe, H.; Shinoda, N.; Okada, S.-I.; et al. Alterations of serum levels of brain-derived neurotrophic factor (BDNF) in depressed patients with or without antidepressants. Biol. Psychiatry 2003, 54, 70-75. [CrossRef]

197. Birkenhäger, T.K.; Geldermans, S.; Broek, W.W.V.D.; Van Beveren, N.; Fekkes, D. Serum brain-derived neurotrophic factor level in relation to illness severity and episode duration in patients with major depression. J. Psychiatr. Res. 2012, 46, 285-289. [CrossRef]

198. Kim, Y.-K.; Lee, H.-P.; Won, S.-D.; Park, E.-Y.; Lee, H.-Y.; Lee, B.-H.; Lee, S.-W.; Yoon, D.; Han, C.; Kim, D.-J.; et al. Low plasma BDNF is associated with suicidal behavior in major depression. Prog. Neuro-Psychopharmacol. Biol. Psychiatry 2007, 31, 78-85. [CrossRef]

199. Molendijk, M.; Bus, B.A.A.; Spinhoven, P.; Penninx, B.W.J.H.; Kenis, G.; Prickaerts, J.; Voshaar, R.C.O.; Elzinga, B.M. Serum levels of brain-derived neurotrophic factor in major depressive disorder: State-trait issues, clinical features and pharmacological treatment. Mol. Psychiatry 2010, 16, 1088-1095. [CrossRef]

200. Bocchio-Chiavetto, L.; Bagnardi, V.; Zanardini, R.; Molteni, R.; Nielsen, M.G.; Placentino, A.; Giovannini, C.; Rillosi, L.; Ventriglia, M.; Riva, M.A.; et al. Serum and plasma BDNF levels in major depression: A replication study and meta-analyses. World J. Biol. Psychiatry 2010, 11, 763-773. [CrossRef]

201. Sen, S.; Duman, R.; Sanacora, G. Serum Brain-Derived Neurotrophic Factor, Depression, and Antidepressant Medications: Meta-Analyses and Implications. Biol. Psychiatry 2008, 64, 527-532. [CrossRef]

202. Fernandes, B.S.; Berk, M.; Turck, C.W.; Steiner, J.; Gonçalves, C.-A. Decreased peripheral brain-derived neurotrophic factor levels are a biomarker of disease activity in major psychiatric disorders: A comparative meta-analysis. Mol. Psychiatry 2013, 19, 750-751. [CrossRef]

203. Noto, C.; Gadelha, A.; Belangero, S.I.; Smith, M.C.; De Aguiar, B.W.; Panizzuti, B.; Mari, J.D.J.; Gama, C.S.; Bressan, R.A.; Brietzke, E. Association of biomarkers and depressive symptoms in schizophrenia. Neurosci. Lett. 2011, 505, 282-285. [CrossRef] [PubMed]

204. Hing, B.; Sathyaputri, L.; Potash, J.B. A comprehensive review of genetic and epigenetic mechanisms that regulateBDNFexpression and function with relevance to major depressive disorder. Am. J. Med. Genet. Part B Neuropsychiatr. Genet. 2017, 177, 143-167. [CrossRef]

205. Diniz, B.S.; Teixeira, A.L.; Machado-Vieira, R.; Talib, L.L.; Gattaz, W.F.; Forlenza, O.V. Reduced serum nerve growth factor in patients with late-life depression. Am. J. Geriatr. Psychiatry 2013, 21, 493-496. [CrossRef] [PubMed]

206. Xiong, P.; Zeng, Y.; Wan, J.; Xiaohan, D.H.; Tan, D.; Lu, J.; Xu, F.; Li, H.Y.; Zhu, Z.; Ma, M. The role of NGF and IL-2 serum level in assisting the diagnosis in first episode schizophrenia. Psychiatry Res. 2011, 189, $72-76$. [CrossRef] 
207. Ziegenhorn, A.A.; Schulte-Herbrüggen, O.; Danker-Hopfe, H.; Malbranc, M.; Hartung, H.-D.; Anders, D.; Lang, U.E.; Steinhagen-Thiessen, E.; Schaub, R.T.; Hellweg, R. Serum neurotrophins-A study on the time course and influencing factors in a large old age sample. Neurobiol. Aging 2007, 28, 1436-1445. [CrossRef]

208. Loch, A.A.; Zanetti, M.V.; de Sousa, R.T.; Chaim, T.M.; Serpa, M.H.; Gattaz, W.F.; Teixeira, A.L.; Machado-Vieira, R. Elevated neurotrophin-3 and neurotrophin 4/5 levels in unmedicated bipolar depression and the effects of lithium. Prog. Neuropsychopharmacol. Biol. Psychiatry 2015, 56, 243-246. [CrossRef] [PubMed]

209. Tseng, P.T.; Chen, Y.W.; Tu, K.Y.; Wang, H.Y.; Chung, W.; Wu, C.K.; Hsu, S.P.; Kuo, H.C.; Lin, P.Y. State-dependent increase in the levels of neurotrophin-3 and neurotrophin-4/5 in patients with bipolar disorder: A meta-analysis. J. Psychiatr. Res. 2016, 79, 86-92. [CrossRef] [PubMed]

210. Walz, J.C.; Magalhaes, P.V.; Giglio, L.M.; Cunha, A.B.; Stertz, L.; Fries, G.R.; Andreazza, A.C.; Kapczinski, F. Increased serum neurotrophin-4/5 levels in bipolar disorder. J. Psychiatr. Res. 2009, 43, 721-723. [CrossRef] [PubMed]

211. Otsuki, K.; Uchida, S.; Watanuki, T.; Wakabayashi, Y.; Fujimoto, M.; Matsubara, T.; Funato, H.; Watanabe, Y. Altered expression of neurotrophic factors in patients with major depression. J. Psychiatr. Res. 2008, 42, 1145-1153. [CrossRef] [PubMed]

212. Munkholm, K.; Pedersen, B.K.; Kessing, L.V.; Vinberg, M. Elevated levels of plasma brain derived neurotrophic factor in rapid cycling bipolar disorder patients. Psychoneuroendocrinology 2014, 47, 199-211. [CrossRef] [PubMed]

213. Aydemir, Ö.; Çubukçuoğlu, Z.; Erdin, S.; Taş, C.; Onur, E.; Berk, M. Oxidative stress markers, cognitive functions, and psychosocial functioning in bipolar disorder: An empirical cross-sectional study. Rev. Bras. Psiquiatr. 2014, 36, 293-297. [CrossRef] [PubMed]

214. Chekalina, N.D.; Klyushnik, T.; Brusov, O.S.; Danilovskaya, E.V.; Deineko, N.L. Identification of specific binding sites for nerve growth factor on human blood platelets and membranes from bovine brain. Bull. Exp. Biol. Med. 1996, 121, 271-273. [CrossRef]

215. Fujimura, H.; Chen, R.; Nakamura, T.; Nakahashi, T.; Kambayashi, J.-I.; Sun, B.; Altar, C.A.; Tandon, N.N. Brain-derived Neurotrophic Factor Is Stored in Human Platelets and Released by Agonist Stimulation. Thromb. Haemost. 2002, 87, 728-734. [CrossRef] [PubMed]

216. Karege, F.; Schwald, M.; Cisse, M. Postnatal developmental profile of brain-derived neurotrophic factor in rat brain and platelets. Neurosci. Lett. 2002, 328, 261-264. [CrossRef]

217. Tamura, S.; Suzuki, H.; Hirowatari, Y.; Hatase, M.; Nagasawa, A.; Matsuno, K.; Kobayashi, S.; Moriyama, T. Release reaction of brain-derived neurotrophic factor (BDNF) through PAR1 activation and its two distinct pools in human platelets. Thromb. Res. 2011, 128, e55-e61. [CrossRef]

218. Amadio, P.; Sandrini, L.; Ieraci, A.; Tremoli, E.; Barbieri, S.S. Effect of Clotting Duration and Temperature on BDNF Measurement in Human Serum. Int. J. Mol. Sci. 2017, 18, 1987. [CrossRef]

219. Hochstrasser, T.; Ehrlich, D.; Sperner-Unterweger, B.; Humpel, C. Antidepressants and Anti-Inflammatory Drugs Differentially Reduce the Release of NGF and BDNF from Rat Platelets. Pharmacopsychiatry 2012, 46, 29-34. [CrossRef]

220. Stoll, P.; Plessow, A.; Bratke, K.; Virchow, J.C.; Lommatzsch, M. Differential effect of clopidogrel and aspirin on the release of BDNF from platelets. J. Neuroimmunol. 2011, 238, 104-106. [CrossRef]

221. Naegelin, Y.; Dingsdale, H.; Säuberli, K.; Schädelin, S.; Kappos, L.; Barde, Y.-A. Measuring and Validating the Levels of Brain-Derived Neurotrophic Factor in Human Serum. Eneuro 2018, 5. [CrossRef]

222. Lee, B.-H.; Kim, Y.-K. Reduced platelet BDNF level in patients with major depression. Prog. Neuro-Psychopharmacol. Biol. Psychiatry 2009, 33, 849-853. [CrossRef]

223. Pandey, G.N.; Dwivedi, Y. Brain-derived neurotrophic factor gene and protein expression in pediatric and adult depressed subjects. Prog. Neuro-Psychopharmacol. Biol. Psychiatry 2010, 34, 1161. [CrossRef]

224. Serra-Millàs, M.; López-Vílchez, I.; Navarro, V.; Galán, A.-M.; Escolar, G.; Penadés, R.; Catalán, R.; Fañanás, L.; Arias, B.; Gastó, C. Changes in plasma and platelet BDNF levels induced by S-citalopram in major depression. Psychopharmacology 2011, 216, 1-8. [CrossRef] [PubMed]

225. Sandrini, L.; Ieraci, A.; Amadio, P.; Veglia, F.; Popoli, M.; Lee, F.S.; Tremoli, E.; Barbieri, S.S. Sub-Chronic Stress Exacerbates the Pro-Thrombotic Phenotype in BDNFVal/Met Mice: Gene-Environment Interaction in the Modulation of Arterial Thrombosis. Int. J. Mol. Sci. 2018, 19, 3235. [CrossRef] 
226. Zhang, C.; Wang, K.; Yang, L.; Liu, R.; Chu, Y.; Qin, X.; Yang, P.; Yu, H. Lipid metabolism in inflammation-related diseases. Analyst 2018, 143, 4526-4536. [CrossRef] [PubMed]

227. Reiner, Ž. Hypertriglyceridaemia and risk of coronary artery disease. Nat. Rev. Cardiol. 2017, 14, 401-411. [CrossRef] [PubMed]

228. Akkerman, J.W.N. From low-density lipoprotein to platelet activation. Int. J. Biochem. Cell Biol. 2008, 40, 2374-2378. [CrossRef] [PubMed]

229. Libby, P.; Ridker, P.M.; Maseri, A. Inflammation and Atherosclerosis. Circulation 2002, 105, 1135-1143. [CrossRef]

230. Saari, K.; Jokelainen, J.; Veijola, J.; Koponen, H.; Jones, P.B.; Savolainen, M.; Jarvelin, M.-R.; Laurén, L.; Isohanni, M.; Lindeman, S. Serum lipids in schizophrenia and other functional psychoses: A general population northern Finland 1966 birth cohort survey. Acta Psychiatr. Scand. 2004, 110, 279-285. [CrossRef]

231. Andreassen, O.A.; Djurovic, S.; Thompson, W.K.; Schork, A.J.; Kendler, K.S.; O’Donovan, M.C.; Rujescu, D.; Werge, T.; van de Bunt, M.; Morris, A.P.; et al. Improved detection of common variants associated with schizophrenia by leveraging pleiotropy with cardiovascular-disease risk factors. Am. J. Hum. Genet. 2013, 92, 197-209. [CrossRef]

232. Solberg, D.; Bentsen, H.; Refsum, H.; Andreassen, O.A. Lipid profiles in schizophrenia associated with clinical traits: A five year follow-up study. BMC Psychiatry 2016, 16, 299. [CrossRef]

233. Kahl, K.G.; Greggersen, W.; Schweiger, U.; Cordes, J.; Balijepalli, C.; Lösch, C.; Moebus, S. Prevalence of the metabolic syndrome in unipolar major depression. Eur. Arch. Psychiatry Clin. Neurosci. 2011, 262, 313-320. [CrossRef] [PubMed]

234. Persons, J.E.; Fiedorowicz, J.G. Depression and serum low-density lipoprotein: A systematic review and meta-analysis. J. Affect. Disord. 2016, 206, 55-67. [CrossRef] [PubMed]

235. Parekh, A.; Smeeth, D.; Milner, Y.; Thuret, S. The Role of Lipid Biomarkers in Major Depression. Healthcare 2017, 5, 5. [CrossRef] [PubMed]

236. Wagner, C.; Musenbichler, C.; Böhm, L.; Färber, K.; Fischer, A.-I.; Von Nippold, F.; Winkelmann, M.; Richter-Schmidinger, T.; Mühle, C.; Kornhuber, J.; et al. LDL cholesterol relates to depression, its severity, and the prospective course. Prog. Neuro-Psychopharmacol. Biol. Psychiatry 2019, 92, 405-411. [CrossRef]

237. Moreira, F.P.; Jansen, K.; Cardoso, T.D.A.; Mondin, T.C.; Magalhaes, P.V.S.; Kapczinski, F.; Souza, L.D.D.M.; Da Silva, R.A.; Oses, J.P.; Wiener, C.D. Metabolic syndrome in subjects with bipolar disorder and major depressive disorder in a current depressive episode: Population-based study. J. Psychiatr. Res. 2017, 92, 119-123. [CrossRef]

238. Enko, D.; Brandmayr, W.; Halwachs-Baumann, G.; Schnedl, W.J.; Meinitzer, A.; Kriegshäuser, G. Prospective plasma lipid profiling in individuals with and without depression. Lipids Health Dis. 2018, 17, 149. [CrossRef]

239. Horsten, M.; Wamala, S.P.; Vingerhoets, A.; Orth-Gomer, K. Depressive Symptoms, Social Support, and Lipid Profile in Healthy Middle-Aged Women. Psychosom. Med. 1997, 59, 521-528. [CrossRef]

240. Olusi, S.O.; Fido, A.A. Serum lipid concentrations in patients with major depressive disorder. Biol. Psychiatry 1996, 40, 1128-1131. [CrossRef]

241. Partonen, T.; Haukka, J.; Virtamo, J.; Taylor, P.R.; Lönnqvist, J. Association of low serum total cholesterol with major depression and suicide. Br. J. Psychiatry 1999, 175, 259-262. [CrossRef]

242. Almeida, O.P.; Yeap, B.B.; Hankey, G.J.; Golledge, J.; Flicker, L. HDL cholesterol and the risk of depression over 5 years. Mol. Psychiatry 2013, 19, 637-638. [CrossRef]

243. Morgan, R.E.; Palinkas, L.A.; Barret-Connor, E.L.; Wingard, D.L. Plasma Cholesterol and Depressive Symptoms in Older Men. Endocrinologist 1993, 3, 230. [CrossRef]

244. Äijänseppä, S.; Kivinen, P.; Helkala, E.-L.; Kivelä, S.-L.; Tuomilehto, J.; Nissinen, A. Serum cholesterol and depressive symptoms in elderly Finnish men. Int. J. Geriatr. Psychiatry 2002, 17, 629-634. [CrossRef]

245. Hummel, J.; Westphal, S.; Weber-Hamann, B.; Gilles, M.; Lederbogen, F.; Angermeier, T.; Luley, C.; Deuschle, M.; Kopf, D. Serum Lipoproteins Improve After Successful Pharmacologic Antidepressant Treatment. J. Clin. Psychiatry 2011, 72, 885-891. [CrossRef] [PubMed]

246. Ong, K.L.; Morris, M.J.; McClelland, R.L.; Maniam, J.; Allison, M.A.; Rye, K.-A. Lipids, lipoprotein distribution and depressive symptoms: The Multi-Ethnic Study of Atherosclerosis. Transl. Psychiatry 2016, 6, e962. [CrossRef] [PubMed] 
247. Wei, Y.-G.; Cai, D.-B.; Liu, J.; Liu, R.-X.; Wang, S.-B.; Tang, Y.-Q.; Zheng, W.; Wang, F. Cholesterol and triglyceride levels in first-episode patients with major depressive disorder: A meta-analysis of case-control studies. J. Affect. Disord. 2020, 266, 465-472. [CrossRef] [PubMed]

248. Maes, M. Inflammatory and oxidative and nitrosative stress pathways underpinning chronic fatigue, somatization and psychosomatic symptoms. Curr. Opin. Psychiatry 2009, 22, 75-83. [CrossRef] [PubMed]

249. Sarandol, A.; Sarandol, E.; Eker, S.S.; Erdinc, S.; Vatansever, E.; Kirli, S. Major depressive disorder is accompanied with oxidative stress: Short-term antidepressant treatment does not alter oxidative-antioxidative systems. Hum. Psychopharmacol. Clin. Exp. 2007, 22, 67-73. [CrossRef]

250. Kotan, V.O.; Sarandol, E.; Kirhan, E.; Ozkaya, G.; Kirli, S. Effects of long-term antidepressant treatment on oxidative status in major depressive disorder: A 24-week follow-up study. Prog. Neuro-Psychopharmacol. Biol. Psychiatry 2011, 35, 1284-1290. [CrossRef] [PubMed]

251. Stefanescu, C.; Ciobica, A. The relevance of oxidative stress status in first episode and recurrent depression. J. Affect. Disord. 2012, 143, 34-38. [CrossRef]

252. Maes, M.; Bonifacio, K.L.; Morelli, N.R.; Vargas, H.O.; Barbosa, D.S.; Carvalho, A.F.; Nunes, S.O.V. Major Differences in Neurooxidative and Neuronitrosative Stress Pathways Between Major Depressive Disorder and Types I and II Bipolar Disorder. Mol. Neurobiol. 2018, 56, 141-156. [CrossRef]

253. Camkurt, M.A.; Fındıkl1, E.; Izci, F.; Kurutaş, E.B.; Tuman, T.C. Evaluation of malondialdehyde, superoxide dismutase and catalase activity and their diagnostic value in drug naïve, first episode, non-smoker major depression patients and healthy controls. Psychiatry Res. 2016, 238, 81-85. [CrossRef] [PubMed]

254. Ogłodek, E.A. Changes in the concentrations of inflammatory and oxidative status biomediators (MIP-1 $\alpha$, PMN elastase, MDA, and IL-12) in depressed patients with and without posttraumatic stress disorder. Pharmacol. Rep. 2018, 70, 110-118. [CrossRef] [PubMed]

255. Milaneschi, Y.; Cesari, M.; Simonsick, E.M.; Vogelzangs, N.; Kanaya, A.M.; Yaffe, K.; Patrignani, P.; Metti, A.; Kritchevsky, S.B.; Pahor, M.; et al. Lipid Peroxidation and Depressed Mood in Community-Dwelling Older Men and Women. PLoS ONE 2013, 8, e65406. [CrossRef] [PubMed]

256. Dimopoulos, N.; Piperi, C.; Psarra, V.; Lea, R.W.; Kalofoutis, A. Increased plasma levels of 8-iso-PGF2 $\alpha$ and IL-6 in an elderly population with depression. Psychiatry Res. 2008, 161, 59-66. [CrossRef] [PubMed]

257. Wolkowitz, O.M.; Mellon, S.H.; Epel, E.S.; Lin, J.; Dhabhar, F.S.; Su, Y.; Reus, V.; Rosser, R.; Burke, H.M.; Kupferman, E.; et al. Leukocyte Telomere Length in Major Depression: Correlations with Chronicity, Inflammation and Oxidative Stress-Preliminary Findings. PLoS ONE 2011, 6, e17837. [CrossRef] [PubMed]

258. Maes, M.; Mihaylova, I.; Kubera, M.; Uytterhoeven, M.; Vrydags, N.; Bosmans, E. Increased plasma peroxides and serum oxidized low density lipoprotein antibodies in major depression: Markers that further explain the higher incidence of neurodegeneration and coronary artery disease. J. Affect. Disord. 2010, 125, 287-294. [CrossRef] [PubMed]

259. Tsuboi, H.; Sakakibara, H.; Tatsumi, A.; Yamakawa-Kobayashi, K.; Matsunaga, M.; Kaneko, H.; Shimoi, K. Serum IL-6 levels and oxidation rate of LDL cholesterol were related to depressive symptoms independent of omega-3 fatty acids among female hospital and nursing home workers in Japan. J. Affect. Disord. 2019, 249, 385-393. [CrossRef] [PubMed]

260. Guardiola, M.; Solá, R.; Vallvé, J.-C.; Girona, J.; Godàs, G.; Heras, M.; González, M.; Rock, E.; Winklhoffer-Roob, B.M.; Masana, L.; et al. Body mass index correlates with atherogenic lipoprotein profile even in nonobese, normoglycemic, and normolipidemic healthy men. J. Clin. Lipidol. 2015, 9, 824-831.e1. [CrossRef]

261. Hurtado-Roca, Y.; Bueno, H.; Fernández-Ortiz, A.; Ordovas, J.M.; Ibañez, B.; Fuster, V.; Rodriguez-Artalejo, F.; Laclaustra, M. Oxidized LDL Is Associated with Metabolic Syndrome Traits Independently of Central Obesity and Insulin Resistance. Diabetes 2016, 66, 474-482. [CrossRef]

262. Siegel-Axel, D.I.; Daub, K.; Seizer, P.; Lindemann, S.; Gawaz, M. Platelet lipoprotein interplay: Trigger of foam cell formation and driver of atherosclerosis. Cardiovasc. Res. 2008, 78, 8-17. [CrossRef]

263. Podrez, E.A.; Byzova, T.V.; Febbraio, M.; Salomon, R.G.; Ma, Y.; Valiyaveettil, M.; Poliakov, E.; Sun, M.; Finton, P.J.; Curtis, B.R.; et al. Platelet CD36 links hyperlipidemia, oxidant stress and a prothrombotic phenotype. Nat. Med. 2007, 13, 1086-1095. [CrossRef] [PubMed]

264. Magwenzi, S.; Woodward, C.; Wraith, K.S.; Aburima, A.; Raslan, Z.; Jones, H.; McNeil, C.; Wheatcroft, S.; Yuldasheva, N.; Febbriao, M.; et al. Oxidized LDL activates blood platelets through CD36/NOX2-mediated inhibition of the cGMP/protein kinase G signaling cascade. Blood 2015, 125, 2693-2703. [CrossRef] [PubMed] 
265. Chatterjee, M.; Rath, D.; Schlotterbeck, J.; Rheinlaender, J.; Walker-Allgaier, B.; Alnaggar, N.; Zdanyte, M.; Müller, I.; Borst, O.; Geisler, T.; et al. Regulation of oxidized platelet lipidome: Implications for coronary artery disease. Eur. Hear. J. 2017, 38, 1993-2005. [CrossRef] [PubMed]

266. Forrester, S.J.; Kikuchi, D.S.; Hernandes, M.S.; Xu, Q.; Griendling, K.K. Reactive Oxygen Species in Metabolic and Inflammatory Signaling. Circ. Res. 2018, 122, 877-902. [CrossRef]

267. Panth, N.; Paudel, K.R.; Parajuli, K. Reactive Oxygen Species: A Key Hallmark of Cardiovascular Disease. Adv. Med. 2016, 2016, 1-12. [CrossRef]

268. Förstermann, U.; Xia, N.; Li, H. Roles of Vascular Oxidative Stress and Nitric Oxide in the Pathogenesis of Atherosclerosis. Circ. Res. 2017, 120, 713-735. [CrossRef]

269. Hirata, Y.; Yamamoto, E.; Tokitsu, T.; Kusaka, H.; Fujisue, K.; Kurokawa, H.; Sugamura, K.; Maeda, H.; Tsujita, K.; Kaikita, K.; et al. Reactive Oxygen Metabolites are Closely Associated with the Diagnosis and Prognosis of Coronary Artery Disease. J. Am. Hear. Assoc. 2015, 4, e001451. [CrossRef]

270. Zhang, Y.; Murugesan, P.; Huang, K.; Cai, H. NADPH oxidases and oxidase crosstalk in cardiovascular diseases: Novel therapeutic targets. Nat. Rev. Cardiol. 2019, 17, 170-194. [CrossRef]

271. Lopresti, A.L.; Maker, G.L.; Hood, S.D.; Drummond, P.D. A review of peripheral biomarkers in major depression: The potential of inflammatory and oxidative stress biomarkers. Prog. Neuro-Psychopharmacol. Biol. Psychiatry 2014, 48, 102-111. [CrossRef]

272. Salim, S. Oxidative Stress and the Central Nervous System. J. Pharmacol. Exp. Ther. 2016, 360, $201-205$. [CrossRef]

273. Black, C.N.; Bot, M.; Scheffer, P.G.; Cuijpers, P.; Penninx, B.W.J.H. Is depression associated with increased oxidative stress? A systematic review and meta-analysis. Psychoneuroendocrinology 2015, 51, 164-175. [CrossRef] [PubMed]

274. Rossetti, A.C.; Paladini, M.S.; Riva, M.A.; Molteni, R. Oxidation-reduction mechanisms in psychiatric disorders: A novel target for pharmacological intervention. Pharmacol. Ther. 2020, 210, 107520. [CrossRef]

275. Ibi, M.; Liu, J.; Arakawa, N.; Kitaoka, S.; Kawaji, A.; Matsuda, K.I.; Iwata, K.; Matsumoto, M.; Katsuyama, M.; Zhu, K.; et al. Depressive-Like Behaviors Are Regulated by NOX1/NADPH Oxidase by Redox Modification of NMDA Receptor 1. J. Neurosci. 2017, 37, 4200-4212. [CrossRef]

276. Liu, T.; Zhong, S.; Liao, X.; Chen, J.; He, T.; Lai, S.; Jia, Y. A Meta-analysis of oxidative stress markers in depression. PLoS ONE 2015, 10, e0138904. [CrossRef] [PubMed]

277. Lindqvist, D.; Dhabhar, F.S.; James, S.J.; Hough, C.M.; Jain, F.A.; Bersani, F.S.; Reus, V.I.; Verhoeven, J.E.; Epel, E.S.; Mahan, L.; et al. Oxidative stress, inflammation and treatment response in major depression. Psychoneuroendocrinology 2017, 76, 197-205. [CrossRef] [PubMed]

278. Herken, H.; Gurel, A.; Selek, S.; Armutcu, F.; Ozen, M.E.; Bulut, M.; Kap, O.; Yumru, M.; Savas, H.A.; Akyol, O. Adenosine Deaminase, Nitric Oxide, Superoxide Dismutase, and Xanthine Oxidase in Patients with Major Depression: Impact of Antidepressant Treatment. Arch. Med Res. 2007, 38, 247-252. [CrossRef] [PubMed]

279. Selek, S.; Savas, H.A.; Gergerlioglu, H.S.; Bulbul, F.; Uz, E.; Yumru, M. The course of nitric oxide and superoxide dismutase during treatment of bipolar depressive episode. J. Affect. Disord. 2008, 107, 89-94. [CrossRef]

280. Klinedinst, N.J.; Regenold, W.T. A mitochondrial bioenergetic basis of depression. J. Bioenerg. Biomembr. 2014, 47, 155-171. [CrossRef]

281. Bansal, Y.; Kuhad, A. Mitochondrial Dysfunction in Depression. Curr. Neuropharmacol. 2016, 14, 610-618. [CrossRef]

282. Bergmeier, W.; Piffath, C.L.; Cheng, G.; Dole, V.S.; Zhang, Y.; Von Andrian, U.H.; Wagner, D.D. Tumor Necrosis Factor- $\alpha$-Converting Enzyme (ADAM17) Mediates GPIb $\alpha$ Shedding from Platelets In Vitro and In Vivo. Blood 2004, 104, 841. [CrossRef]

283. Gardiner, E.; Arthur, J.F.; Kahn, M.L.; Berndt, M.C.; Andrews, R.K. Regulation of platelet membrane levels of glycoprotein VI by a platelet-derived metalloproteinase. Blood 2004, 104, 3611-3617. [CrossRef] [PubMed]

284. Baaten, C.C.F.M.J.; Swieringa, F.; Misztal, T.; Mastenbroek, T.G.; Feijge, M.A.H.; Bock, P.E.; Donners, M.M.P.C.; Collins, P.W.; Li, R.; Van Der Meijden, P.E.J.; et al. Platelet heterogeneity in activation-induced glycoprotein shedding: Functional effects. Blood Adv. 2018, 2, 2320-2331. [CrossRef]

285. Khodadi, E. Platelet Function in Cardiovascular Disease: Activation of Molecules and Activation by Molecules. Cardiovasc. Toxicol. 2019, 20,1-10. [CrossRef] 
286. Sandrini, L.; Ieraci, A.; Amadio, P.; Popoli, M.; Tremoli, E.; Barbieri, S.S. Apocynin Prevents Abnormal Megakaryopoiesis and Platelet Activation Induced by Chronic Stress. Oxid. Med. Cell. Longev. 2017, 2017, 9258937. [CrossRef] [PubMed]

287. Qiao, J.; Arthur, J.F.; Gardiner, E.E.; Andrews, R.K.; Zeng, L.; Xu, K. Regulation of platelet activation and thrombus formation by reactive oxygen species. Redox Biol. 2018, 14, 126-130. [CrossRef] [PubMed]

288. Jang, J.Y. Reactive oxygen species play a critical role in collagen-induced platelet activation via SHP-2 oxidation. Antioxid Redox Signal 2014, 20, 2528-2540. [CrossRef]

289. Fuentes, E.; Palomo, I. Role of oxidative stress on platelet hyperreactivity during aging. Life Sci. 2016, 148, 17-23. [CrossRef]

290. Bakdash, N.; Williams, M.S. Spatially distinct production of reactive oxygen species regulates platelet activation. Free. Radic. Biol. Med. 2008, 45, 158-166. [CrossRef]

291. Begonja, A.J.; Stepan, G.; Geiger, J.; Aktas, B.; Pozgajova, M.; Nieswandt, B.; Walter, U. Platelet $\mathrm{NAD}(\mathrm{P}) \mathrm{H}$-oxidase-generated ROS production regulates alphaIlbbeta3-integrin activation independent of the NO/cGMP pathway. Blood 2005, 106, 2757-2760. [CrossRef]

292. Kim, K.; Li, J.; Tseng, A.; Andrews, R.K.; Cho, J. NOX2 is critical for heterotypic neutrophil-platelet interactions during vascular inflammation. Blood 2015, 126, 1952-1964. [CrossRef]

293. Wachowicz, B.; Olas, B.; Zbikowska, H.M.; Buczyński, A. Generation of reactive oxygen species in blood platelets. Platelets 2002, 13, 175-182. [CrossRef] [PubMed]

294. Pignatelli, P.; Sanguigni, V.; Paola, S.G.; Coco, E.L.; Lenti, L.; Violi, F. Vitamin C inhibits platelet expression of CD40 ligand. Free. Radic. Biol. Med. 2005, 38, 1662-1666. [CrossRef] [PubMed]

295. Bauer, J.; Ripperger, A.; Frantz, S.; Ergün, S.; Schwedhelm, E.; Benndorf, R.A. Pathophysiology of isoprostanes in the cardiovascular system: Implications of isoprostane-mediated thromboxane A2receptor activation. Br. J. Pharmacol. 2014, 171, 3115-3131. [CrossRef] [PubMed]

296. Audoly, L.P.; Rocca, B.; Fabre, J.-E.; Koller, B.H.; Thomas, D.; Loeb, A.L.; Coffman, T.M.; Fitzgerald, G.A. Cardiovascular Responses to the Isoprostanes iPF $2 \alpha$-III and iPE 2 -III Are Mediated via the Thromboxane A 2 Receptor In Vivo. Circulation 2000, 101, 2833-2840. [CrossRef] [PubMed]

297. Khasawneh, F.T.; Huang, J.-S.; Mir, F.; Srinivasan, S.; Tiruppathi, C.; Le Breton, G.C. Characterization of isoprostane signaling: Evidence for a unique coordination profile of 8-iso-PGF(2alpha) with the thromboxane A(2) receptor, and activation of a separate cAMP-dependent inhibitory pathway in human platelets. Biochem. Pharmacol. 2008, 75, 2301-2315. [CrossRef] [PubMed]

298. Hroudová, J.; Fišar, Z.; Kitzlerova, E.; Zvěřová, M.; Raboch, J. Mitochondrial respiration in blood platelets of depressive patients. Mitochondrion 2013, 13, 795-800. [CrossRef]

299. Moreno, J.; Gaspar, E.; López-Bello, G.; Juárez, E.; Alcázar-Leyva, S.; González-Trujano, E.; Pavón, L.; Alvarado-Vásquez, N. Increase in nitric oxide levels and mitochondrial membrane potential in platelets of untreated patients with major depression. Psychiatry Res. 2013, 209, 447-452. [CrossRef]

300. Van Der Meijden, P.E.J.; Heemskerk, J.W.M. Platelet biology and functions: New concepts and clinical perspectives. Nat. Rev. Cardiol. 2018, 16, 166-179. [CrossRef]

301. Halaris, A. Inflammation-Associated Co-morbidity Between Depression and Cardiovascular Disease. Curr. Top. Behav. Neurosci. 2017, 31, 45-70. [CrossRef]

302. Milenkovic, V.M.; Stanton, E.H.; Nothdurfter, C.; Rupprecht, R.; Wetzel, C.H. The Role of Chemokines in the Pathophysiology of Major Depressive Disorder. Int. J. Mol. Sci. 2019, 20, 2283. [CrossRef]

303. Noels, H.; Weber, C.; Koenen, R.R. Chemokines as Therapeutic Targets in Cardiovascular Disease. Arter. Thromb. Vasc. Biol. 2019, 39, 583-592. [CrossRef] [PubMed]

304. Aukrust, P.; Halvorsen, B.; Yndestad, A.; Ueland, T.; Øie, E.; Otterdal, K.; Gullestad, L.; DamåsJ, K. Chemokines and Cardiovascular Risk. Arter. Thromb. Vasc. Biol. 2008, 28, 1909-1919. [CrossRef] [PubMed]

305. Eschäfer, A.; Schulz, C.; Eigenthaler, M.; Fraccarollo, D.; Kobsar, A.; Gawaz, M.; Ertl, G.; Walter, U.; Bauersachs, J. Novel role of the membrane-bound chemokine fractalkine in platelet activation and adhesion. Blood 2004, 103, 407-412. [CrossRef]

306. McDermott, D.H.; Halcox, J.P.; Schenke, W.H.; Waclawiw, M.A.; Merrell, M.N.; Epstein, N.; Quyyumi, A.A.; Murphy, P.M. Association between polymorphism in the chemokine receptor CX3CR1 and coronary vascular endothelial dysfunction and atherosclerosis. Circ. Res. 2001, 89, 401-407. [CrossRef] [PubMed] 
307. Leighton, S.P.; Nerurkar, L.; Krishnadas, R.; Johnman, C.; Graham, G.J.; Cavanagh, J. Chemokines in depression in health and in inflammatory illness: A systematic review and meta-analysis. Mol. Psychiatry 2017, 23, 48-58. [CrossRef]

308. Grassi-Oliveira, R.; Brieztke, E.; Teixeira, A.; Pezzi, J.C.; Zanini, M.; Lopes, R.P.; Bauer, M.E. Peripheral chemokine levels in women with recurrent major depression with suicidal ideation. Rev. Bras. Psiquiatr. 2012, 34, 71-75. [CrossRef] [PubMed]

309. Ogłodek, E.A.; Szota, A.M.; Just, M.J.; Moś, D.; Araszkiewicz, A. Comparison of chemokines (CCL-5 and SDF-1), chemokine receptors (CCR-5 and CXCR-4) and IL-6 levels in patients with different severities of depression. Pharmacol. Rep. 2014, 66, 920-926. [CrossRef]

310. Simon, N.M.; McNamara, K.; Chow, C.; Maser, R.; Papakostas, G.; Pollack, M.; Nierenberg, A.; Fava, M.; Wong, K. A detailed examination of cytokine abnormalities in Major Depressive Disorder. Eur. Neuropsychopharmacol. 2008, 18, 230-233. [CrossRef]

311. Ho, P.-S.; Yeh, Y.-W.; Huang, S.-Y.; Liang, C.-S. A shift toward T helper 2 responses and an increase in modulators of innate immunity in depressed patients treated with escitalopram. Psychoneuroendocrinology 2015, 53, 246-255. [CrossRef]

312. Ferroni, P.; Basili, S.; Davì, G. Platelet activation, inflammatory mediators and hypercholesterolemia. Curr. Vasc. Pharmacol. 2003,1,157-169. [CrossRef]

313. Merendino, R.A.; Di Pasquale, G.; De Luca, F.; Di Pasquale, L.; Ferlazzo, E.; Martino, G.; Palumbo, M.C.; Morabito, F.; Gangemi, S. Involvement of fractalkine and macrophage inflammatory protein-1 alpha in moderate-severe depression. Mediat. Inflamm. 2004, 13, 205-207. [CrossRef] [PubMed]

314. Miranda, D.O.; Anatriello, E.; Azevedo, L.R.; Santos, J.C.; Cordeiro, J.F.C.; Peria, F.M.; Flória-Santos, M.; Pereira-Da-Silva, G. Fractalkine (C-X3-C motif chemokine ligand 1) as a potential biomarker for depression and anxiety in colorectal cancer patients. Biomed. Rep. 2017, 7, 188-192. [CrossRef] [PubMed]

315. García-Marchena, N.; Barrera, M.; Mestre-Pintó, J.I.; Araos, P.; Serrano, A.; Pérez-Mañá, C.; Papaseit, E.; Fonseca, F.; Ruiz, J.J.; De Fonseca, F.R.; et al. Inflammatory mediators and dual depression: Potential biomarkers in plasma of primary and substance-induced major depression in cocaine and alcohol use disorders. PLoS ONE 2019, 14, e0213791. [CrossRef] [PubMed]

316. Bai, Y.-M.; Su, T.-P.; Tsai, S.-J.; Wen-Fei, C.; Li, C.-T.; Pei-Chi, T.; Mu-Hong, C. Comparison of inflammatory cytokine levels among type I/type II and manic/hypomanic/euthymic/depressive states of bipolar disorder. J. Affect. Disord. 2014, 166, 187-192. [CrossRef] [PubMed]

317. Sutcigil, L.; Oktenli, C.; Musabak, U.; Bozkurt, A.; Cansever, A.; Uzun, O.; Sanisoglu, S.Y.; Yesilova, Z.; Ozmenler, N.; Ozsahin, A.; et al. Pro- and anti-inflammatory cytokine balance in major depression: Effect of sertraline therapy. Clin. Dev. Immunol. 2008, 2007, 1-6. [CrossRef]

318. Tajfard, M.; Latiff, L.A.; Rahimi, H.R.; Mouhebati, M.; Esmaily, H.; Taghipour, A.; Mahdipour, E.; Davari, H.; Saghiri, Z.; Hanachi, P.; et al. Serum inflammatory cytokines and depression in coronary artery disease. Iran. Red Crescent Med. J. 2014, 16, 17111. [CrossRef]

319. Fontenelle, L.; Barbosa, I.G.; Luna, J.V.; De Sousa, L.P.; Abreu, M.N.S.; Teixeira, A.L. A cytokine study of adult patients with obsessive-compulsive disorder. Compr. Psychiatry 2012, 53, 797-804. [CrossRef]

320. Jonsdottir, I.H.; Hägg, D.A.; Glise, K.; Ekman, R. Monocyte Chemotactic Protein-1 (MCP-1) and growth factors called into question as markers of prolonged psychosocial stress. PLoS ONE 2009, 4, e7659. [CrossRef]

321. Motivala, S.J.; Sarfatti, A.; Olmos, L.; Irwin, M.R. Inflammatory markers and sleep disturbance in major depression. Psychosom. Med. 2005, 67, 187-194. [CrossRef]

322. Kowalska, M.A.; Ratajczak, J.; Hoxie, J.; Brass, L.F.; Gewirtz, A.; Poncz, M.; Ratajczak, M.Z. Megakaryocyte precursors, megakaryocytes and platelets express the HIV co-receptor CXCR4 on their surface: Determination of response to stromal-derived factor-1 by megakaryocytes and platelets. Br. J. Haematol. 1999, 104, 220-229. [CrossRef]

323. Kowalska, M.A.; Ratajczak, M.Z.; Majka, M.; Jin, J.; Kunapuli, S.; Brass, L.; Poncz, M. Stromal cell-derived factor-1 and macrophage-derived chemokine: 2 chemokines that activate platelets. Blood 2000, 96, 50-57. [CrossRef] [PubMed]

324. Abi-Younes, S.; Sauty, A.; Mach, F.; Sukhova, G.K.; Libby, P.; Luster, A.D. The stromal cell-derived factor-1 chemokine is a potent platelet agonist highly expressed in atherosclerotic plaques. Circ. Res. 2000, 86, 131-138. [CrossRef] [PubMed] 
325. Clemetson, K.J.; Clemetson, J.M.; Proudfoot, A.E.; Power, C.A.; Baggiolini, M.; Wells, T.N. Functional expression of CCR1, CCR3, CCR4, and CXCR4 chemokine receptors on human platelets. Blood 2000, 96, 4046-4054. [CrossRef] [PubMed]

326. Flierl, U.; Fraccarollo, D.; Lausenmeyer, E.; Rosenstock, T.; Schulz, C.; Massberg, S.; Bauersachs, J.; Schäfer, A. Fractalkine Activates a Signal Transduction Pathway Similar to P2Y12and Is Associated with Impaired Clopidogrel Responsiveness. Arter. Thromb. Vasc. Biol. 2012, 32, 1832-1840. [CrossRef] [PubMed]

327. Postea, O.; Vasina, E.M.; Cauwenberghs, S.; Projahn, D.; Liehn, E.A.; Lievens, D.; Theelen, W.; Kramp, B.K.; Butoi, E.D.; Soehnlein, O.; et al. Contribution of Platelet CX3CR1 to Platelet-Monocyte Complex Formation and Vascular Recruitment During Hyperlipidemia. Arter. Thromb. Vasc. Biol. 2012, 32, 1186-1193. [CrossRef] [PubMed]

328. Dos Santos, S.M.; Klinkhardt, U.; Scholich, K.; Nelson, K.; Monsefi, N.; Deckmyn, H.; Kuczka, K.; Zorn, A.; Harder, S. The CX3C chemokine fractalkine mediates platelet adhesion via the von Willebrand receptor glycoprotein Ib. Blood 2011, 117, 4999-5008. [CrossRef]

329. Niswander, L.M.; Fegan, K.H.; Kingsley, P.D.; McGrath, K.E.; Palis, J. SDF-1 dynamically mediates megakaryocyte niche occupancy and thrombopoiesis at steady state and following radiation injury. Blood 2014, 124, 277-286. [CrossRef]

330. Chatterjee, M.; Rath, D.; Gawaz, M. Role of chemokine receptors CXCR4 and CXCR7 for platelet function. Biochem. Soc. Trans. 2015, 43, 720-726. [CrossRef]

331. Gleissner, C.A.; Von Hundelshausen, P.; Ley, K. Platelet Chemokines in Vascular Disease. Arter. Thromb. Vasc. Biol. 2008, 28, 1920-1927. [CrossRef]

332. Karshovska, E.; Weber, C.; Hundelshausen, P.E. Platelet chemokines in health and disease. Thromb. Haemost. 2013, 110, 894-902. [CrossRef]

Publisher's Note: MDPI stays neutral with regard to jurisdictional claims in published maps and institutional affiliations. 